\title{
THE GEOLOGICAL WORK OF THE BAUDIN EXPEDITION IN AUSTRALIA (1801-1803): THE MINERALOGISTS, THE DISCOVERIES AND THE LEGACY
}

\author{
WOLF MAYER \\ Research School of Earth Sciences, Australian National University \\ Canberra,ACT 0200,Australia \\ wolf.mayer@bigpond.com.au
}

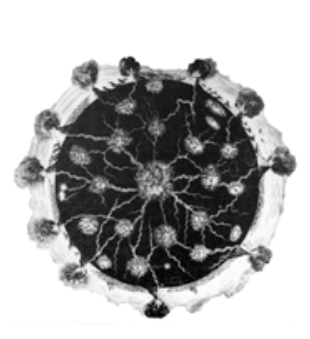

Earth Sciences History

Vol. 28, No. 2, 2009 pp. 293-324

\begin{abstract}
The Baudin expedition to Australia included among its scientific staff Louis Depuch and Joseph Charles Bailly, the first professionally educated geologists to visit this country. Together with the zoologist François Péron, they carried out the earliest geological surveys along large parts of its coast. Their views on the origin of the major rock types were mainly guided by Neptunist thinking. However, in line with the beliefs of a number of French geologists at the time, they recognized basalt as a volcanic rock. Their identification of earth materials was hampered by the still imprecise definition of the physical properties of minerals and rocks. Their work provided the first detailed descriptions of the major rock types and their distribution along the margins of the continent and its islands, and led to some tentative conclusions with regard to the presence of mountains in the country's interior. The three investigators concluded that Australia was built on a foundation of granite, overlain by a variety of sedimentary rocks and fringed by extensive deposits of largely unconsolidated sediment, left behind by a retreating sea. Their mistaken identification of dolerite as basalt led them to believe that they had discovered evidence of volcanic activity in Australia. Issues such as the presence of marine organisms in rocks now above sea level, and the finding of various species of mollusks on Australia's shores, known to be extinct in Europe, led to lively discussions among a number of European naturalists.
\end{abstract}

\section{INTRODUCTION}

The French expedition of discovery commanded by Post-Captain Nicolas Baudin, which explored large parts of Australia's coastal regions between 1801 and 1803, deserves to rank as the most successful venture charged with the scientific exploration of the southern continent during its pre- and early colonial period. The charting of extensive parts of Australia's coastline, the recording and interpretation of its physical features, its rock formations and its life forms, as well as the quality and size of its natural history collections, represent a considerable achievement that yielded up new and unexpected insights into the continent's natural world.

Australia, then commonly referred to as New Holland, had been visited by earlier expeditions that were accompanied by one or more persons with scientific qualifications. The most notable of these were the voyages led by James Cook (1728-1779) (Endeavour 1770, Resolution and Discovery 1777), who claimed the eastern half of the continent for the British Crown and named it New South Wales, and who was accompanied on his first voyage by the botanists Joseph Banks (1743-1820) and Daniel Solander (1733-1782); JeanFrançois de La Pérouse (1741-1788) (Boussole and Astrolabe 1788) whose scientific crew included the naturalists Claude-François-Joseph Receveur (1757-1788) and Jean-Andre Mongez (1751-1788); George Vancouver (1757-1798) (Discovery and Chatham 1791) who travelled with the botanist Archibald Menzies (1754-1842); Antoine-Raymond-Joseph de Bruni d'Entrecasteaux (1739-1793) (Recherche and Espérance 1792-1793), who was 
accompanied by the botanist Jacques-Julien de la Billardière (1755-1834), the naturalists Louis Auguste Deschamps (1765-1842), the Abbé Louis Ventenat (1765-1794) and Claude Riche (1762-1797), and by the mineralogist the Abbé Jean Blavier (1764-1828); and Matthew Flinders (1774-1814) (Investigator 1801-1803), who has been credited with the first circumnavigation of Australia and who sailed with the botanist Robert Brown (17731858). However none of these voyages equaled the Baudin expedition in the scale and the scope of its undertaking, in the number and the mix of the scientific personnel that accompanied it and in the extent and variety of its discoveries and its collections.

Nicolas Baudin (1754-1803) (see Figure 1) was born on the Ile de Ré, not far from La Rochelle on the Atlantic coast. He was an experienced navigator who served in both the French Royal Navy and in its Merchant Navy. Between 1788 and 1792 he made three voyages to collect botanical specimens on behalf of the Austrian Emperor Joseph II, which took him to southern Africa and across the Indian Ocean as far as China. In 1796 Baudin, with the support of the French Government, commanded a very successful botanical collecting expedition to the West Indies, which greatly enriched the collections of the Museum of Natural History in Paris. Following his return, in 1798, he submitted an ambitious proposal for a voyage of discovery around the world. A revised plan to explore the coasts of New Holland was eventually approved by the First Consul, Napoleon Bonaparte, in April of 1800. Baudin's unfortunate death on the return voyage in 1803, not only deprived him of the well deserved credit for the scientific success of the voyage, but the animosity shown towards him by those who came to write the history of the enterprise, also ensured that his name was virtually forgotten, particularly in Europe, until recent times.

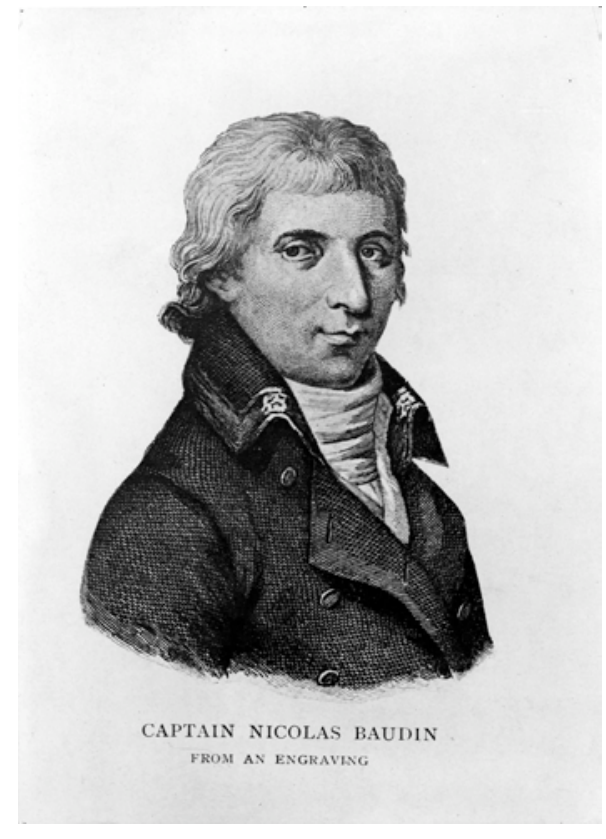

Figure 1 .

Portrait of Post-Captain Nicolas Baudin, Conrad Westermayer (ca 1800). National Library of Australia, Canberra.

The expedition left Le Havre, in October 1800, in the two corvettes the Géographe and the Naturaliste. The crew lists of the two ships showed twenty-two names under the respective headings of 'Naturalists' and 'Savants'. Fourteen of these individuals had formal scientific qualifications, five were gardeners, and three were artists; a further two artists had been entered in the log as assistant gunners (Bonnemain et al. 2001, pp. 113-120; Péron and Freycinet 2006, pp. xlix-liv). It is important to note here that gardeners and artists played quasi-scientific roles in early voyages of discovery; experienced gardeners often possessed 
considerable specialist knowledge in botany, while artists provided detailed illustrations of natural objects and landscapes. The number of the expedition's naturalists and artists was severely depleted when ten of their number withdrew during a stopover at the Ile de France (today's Mauritius). A further six of the naturalists died at various stages of the voyage and two more disembarked at stopovers as the ships were homeward bound. Only six of the original twenty-four 'scientific' staff members completed the voyage and returned to France, all in the Géographe, in 1804. They were the mineralogist Bailly, the geographer Boulanger, and the zoologist Péron, as well as a gardener Guichenot, and the two artists Lesueur and Petit.

The routes followed by the two ships along Australia's coasts until they left Sydney in November 1802, are shown on the map in Figure 2. During the course of their investigations of the continent and its islands the vessels became separated on two occasions for periods of several months, but were reunited, first in Timor late in 1801 and, again, in Sydney in mid-1802. There were, therefore, lengthy periods when the two groups of naturalists were not in contact and worked independently of each other. After a long stay at Sydney, the Naturaliste left on its return voyage and reached Le Havre in June 1803, while the Géographe continued its exploration of the southern and western coasts of the continent and returned to the port of Lorient in March 1804.

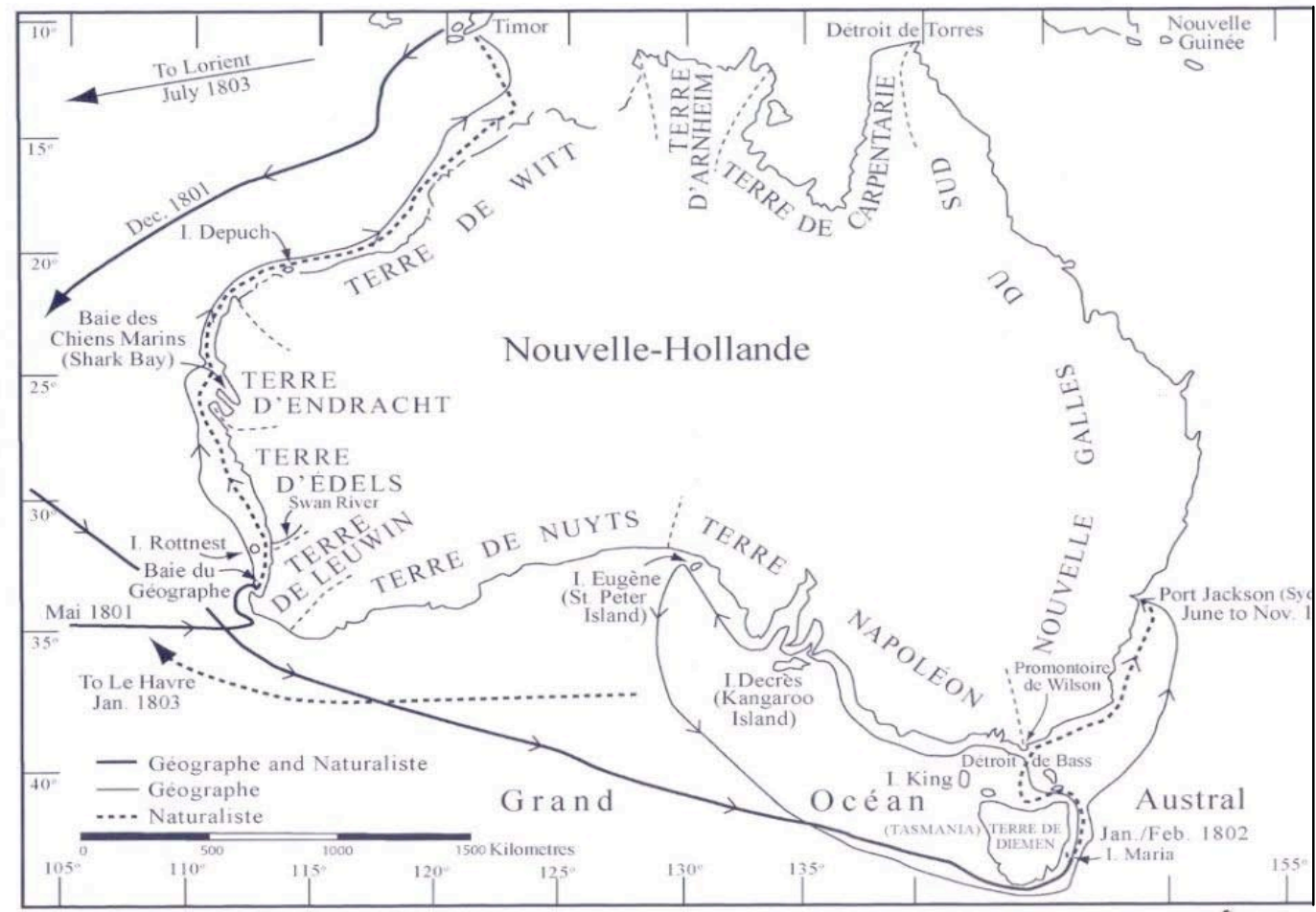

Figure 2. Map of New Holland (Australia). Based on the first published map of the Australian coastline by Freycinet (1811) and showing the routes followed by the Géographe and the Naturaliste. The traces of the ships' tracks have been smoothed out and simplified. 


\section{THE WRITTEN RECORDS OF THE VOYAGE}

In 1806, two years after the return of the expedition, the French Government entrusted the writing of the official history of the voyage to François Péron (1775-1810). Although appointed as a junior member of the scientific staff, Péron proved himself arguably the expedition's most talented and versatile naturalist. He published the first volume of the Voyage in 1807 and was working on the second volume when he died in 1810. Naval Officer Louis Freycinet (1779-1842) completed the work, which appeared in 1816 and in a second edition in 1824 (Péron 1807; Péron and Freycinet 1816, 1824). In recent years, an English translation of the 1824 edition of the Voyage by Christine Cornell appeared in two volumes and in a supplementary publication (Péron and Freycinet 2003, 2006; Péron 2007). These publications contain accounts and discussions of the expedition's geological discoveries, based mostly on the work of the two mineralogists, Louis Depuch (1774-1803) and Joseph Charles Bailly (1777-1844), and on Péron's own investigations. Further geological information is found in the two journals kept by the expedition's commander, which also include copies of a number of reports on scientific topics submitted to him by his naturalists and officers. While some of these reports appear in both of Baudin's journals, others are found in only one of them. His historical journal has appeared in an English translation by Christine Cornell, but has not yet been published in French (Baudin 1974, 2004). A personal journal, which he kept until he reached Sydney in 1802, together with documentation relating to the voyage, has been published in French, but not in English (Bonnemains et al. 2001).

In addition, a range of geological information is contained in reports, journals and catalogues, written and compiled by the ships' naturalists and officers, many of which have been transcribed by Jacqueline Bonnemains, but few of which have been published. An exception is Péron's account of Maria Island, off Tasmania's eastern coast, which has also been translated into English by Christine Cornell and includes a detailed and insightful commentary on its geological content by Max Banks (Plomley et al. 1990). References to unpublished manuscripts of geological interest, cited in this article, are given in the footnotes. Passages quoted from the geological accounts of naturalists and officers were taken from English translations, where these are available. Translations from sources in French and from German publications and manuscripts are those of the author.

\section{THE MINERALOGISTS}

Most scientific observers on earlier voyages of exploration to Australia had expertise in the fields of botany and zoology and took a particular interest in the country's fauna and flora. They paid less attention to the study of its geological phenomena. The initial appointment of four mineralogists to the 'scientific' staff of the Baudin expedition can, therefore, be regarded as exceptional, and as an indication of the importance the authorities in Paris placed on the acquisition of knowledge about the southern continent's physical expressions, its rock formations and potential mineral wealth. A list of questions on aspects of the continent's geology, given to Baudin, and intended for the attention of the mineralogists, has been included in this article as an appendix.

Louis Depuch was appointed as senior mineralogist on board the Géographe, and Joseph Charles Bailly as student or assistant mineralogist sailing on the Naturaliste. Antoine Busche (1776-?), appointed as student mineralogist, unfortunately succumbed to the tearful pleading of his mother at the dockside shortly before the ships' departure and returned with her to Paris (Bonnemains et al. 2001, p. 111). A fourth appointee, Dénys de Montfort (1766-1820), withdrew before joining the ships. The loss of these two mineralogists was however outweighed to some degree by the presence of François Péron who, although he 
made his major contribution in the field of zoology, took a great interest in and carried out much of the expedition's geological work.

\subsection{Louis Depuch}

Louis Depuch was born on 8 October 1774, in the small village of Caumont, in the southwest of France, some $50 \mathrm{~km}$ east of Bordeaux. His father, Alexandre Jean Depuch de Monbreton, who had served as a captain of dragoons, and his mother, Françoise Claire de Malet de Puivalier, were both descended from ancient landed families. The political and social changes that followed the French Revolution led to the seizure of most of the family's estates and to the imprisonment of its head (Laumet 2006). His son Louis must have considered it judicious at this time to delete 'de Monbreton' from his name.

We know little of Depuch's youth and his early education. While he appears to have lived in Paris in 1792, it was not until three years later, at the age of twenty-one, that he commenced his geological studies at the École des mines from where he graduated in the first half of 1798. The École, founded by Louis XVI in 1783 and re-established after the Revolution in 1794, was one of the most highly regarded geological institutions in Europe at that time. Among its staff were the crystallographer and mineralogist René Haüy (17431822 ) and the geologist Déodat de Dolomieu (1750-1801). Based on examination results in geology for the year 1796, Dolomieu ranked Depuch fourteenth in a class of thirty-seven. ${ }^{1}$ Depuch's position in the top half of the class marks him out as a competent, though not an outstanding student in this subject.

Depuch must have gained sufficient practical experience in geology during the two years following his graduation to have been recommended by the Council of Mines for the appointment as Baudin's senior mineralogist (Horner 1987, p. 72). As, in his later reports to his captain he generally added the title 'Mining Engineer' after his signature it may be assumed that he was mainly employed in mining activities during these intervening years. His effective contribution to the expedition's geological work in Australia was limited, however, to the investigation of the continents western coast during the first five months of its survey work. Like many others among the crew, he contracted dysentery during a stopover at Timor and failing health greatly reduced his participation in the expedition's subsequent work. At Sydney, in late 1802, he was transferred to the Naturaliste for the homeward voyage but died on the Ile de France early in the following year (Péron and Freycinet 2003, p. 250).

\subsection{Joseph Charles Bailly}

Depuch's junior colleague, Joseph Charles Bailly was born on 9 November 1777 in Nancy in eastern France, the son of a local lawyer. He studied geology, among other subjects, at the École polytechnique in Paris (then a military institution) between 1796 and 1800, with the intention of serving in the artillery. However, in mid-1800, he resigned from the military and, also on the recommendation of the Council of Mines, joined the expedition to Australia as a junior mineralogist. He remained in good health throughout the voyage and was one of only three qualified scientists to return to France in 1804 . In 1806 he joined the French Navy's hydrographic service, where he carried out valuable work, mostly under the direction of the famous hydrographer Charles-François Beautemps-Beaupré (1766-1854), until his retirement in 1840. He died in 1844 (Prevost and Roman d'Amat 1948, p. 1355). 
François Péron (see Figure 3) was born on 22 August 1775, at Cérilly in the central region of France, into a family of modest social standing (his father was a tailor, his mother the daughter of a merchant draper). After receiving a basic education in his home town, and when still only seventeen years old, he made the surprising decision to join the French Army, then fighting a war against Prussia. He was made a prisoner of war but, having lost the sight of his right eye, was released in 1795 (Duyker 2006, p. 36). Two years later he commenced his studies at the École de médecine in Paris where, in addition to medicine, he took courses in zoology, comparative anatomy, chemistry and physics. The advocacy of his former teacher, Georges Cuvier (1769-1832), among others, led to his appointment as 'student zoologist' of the expedition (Horner 1987, pp. 77-79). Although Péron had no formal education in geology, his immense curiosity in all fields of the natural sciences, his wide-ranging reading of the literature and his close working relationship with Depuch, seem to have equipped him to undertake geological research and provided him with a good understanding of contemporary issues and ideas in geology. He died in his hometown of pulmonary tuberculosis in 1810 .

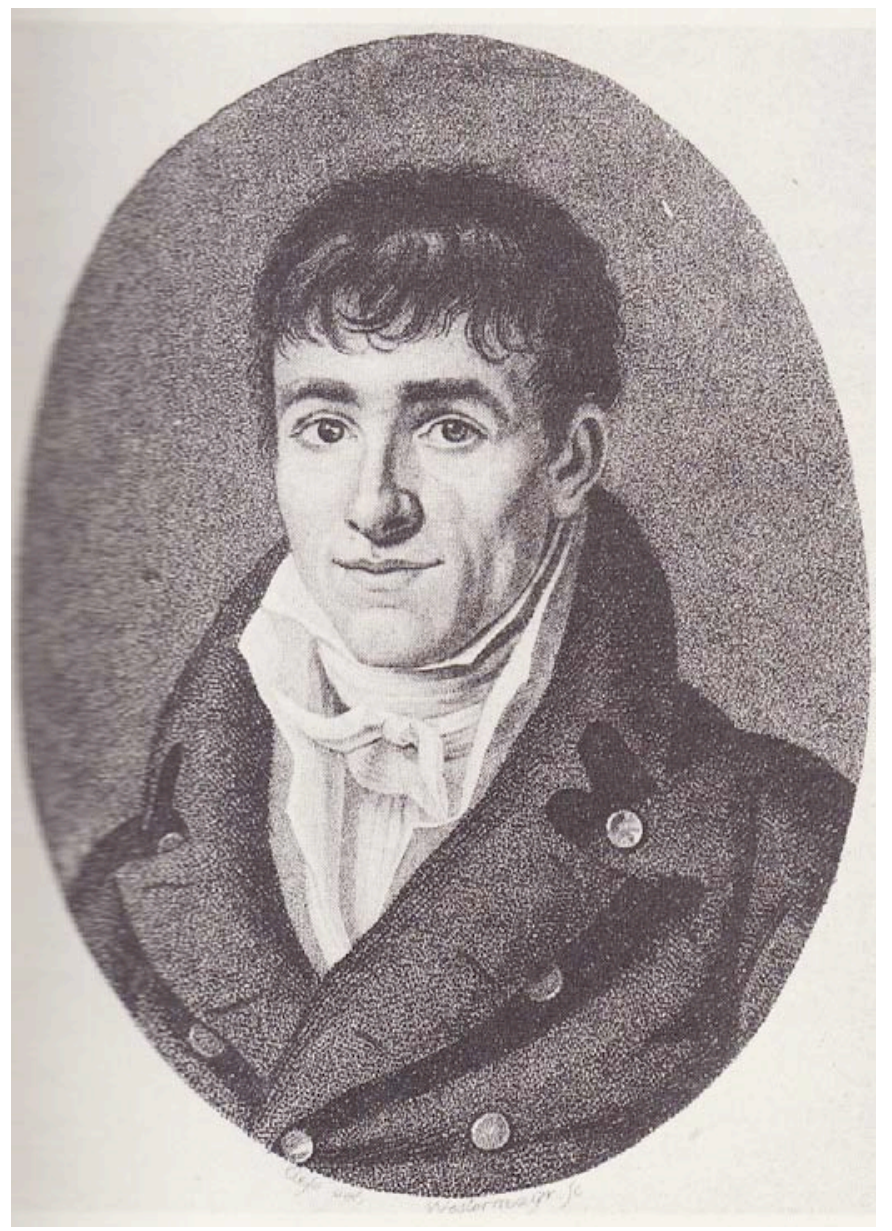

Figure 3

Portrait of François Péron, Conrad Westermayer (1800). National Library of Australia, Canberra. 


\subsection{The ships' officers}

In most early voyages of discovery it was common for the ships' medical staff and its naval officers, who were often well educated, to take an interest in and, sometimes, contribute to the work of the naturalists. Several of Baudin's officers made useful geological observations that contributed to the recording and understanding of Australian geology. The captain himself took a keen interest in natural history and was an accurate observer of natural phenomena.

\section{EQUIPMENT AND METHODS}

While the lists of implements and materials carried on the voyage for use by the expedition's naturalists show numerous items under the headings of 'botany' and 'zoology', the only entry specifically pertaining to geological investigations refers to "six hammers for the mineralogists" (Bonnemains et al. 2001, p. 95). However the ships' stores contained other items of equipment, the uses of which, though not specified, were relevant to their work. These included magnifying glasses, bar magnets, dipping [magnetic] needles, clinometers, blow pipes and a Nicolson balance to measure an object's mass and density.

The field methods used by the expedition's mineralogists to describe and identify mineral and rock samples did not differ greatly from those employed by today's geologists. They took careful note of the diagnostic properties of minerals such as colour, lustre, transparency, fracture, hardness and, more rarely, crystal habits. As Mohs (1773-1839) did not publish his hardness scale until some twenty years later (Mohs 1822-1824, 1825), they tested the hardness of minerals, and also of rocks, with the pointed end of a steel rod or a simple pocket knife and classified them as hard, medium-hard or soft. In their descriptions of rock samples the investigators recorded mineral composition and textural properties, such as the size of crystals or grains, and described the groundmass or matrix in which these were embedded. They used bar magnets and magnetic needles to check for magnetic properties of rock specimens and commented on their specific gravity. To establish the presence of calcium carbonate in their samples they used three different types of acids: nitric, vitriolic [sulphuric] and muriatic [hydrochloric]. Sometimes, if one acid produced no reaction in a sample, they tested it with all three. The acid test allowed them, for example, to distinguish calcite from zeolite. They used a naked flame to test for carbonaceous matter. A rather curious diagnostic test employed by the mineralogists was to sniff the odour given off by a rock specimen after moistening it with the observer's breath. This test was commonly used by early mineralogists, including Werner, who believed that basalt gave off a clayey odour when breathed on. As Werner (1786, pp. 281-282) seems to have confused altered basalts with various types of greywacke, the effectiveness of this test appears to be questionable (Carozzi 2000, p. 611).

\section{VIEWS ON THE CLASSIFICATION AND ORIGIN OF ROCKS}

At the time the Baudin expedition left France, the most widely accepted scheme for the ordering of rock types into specific categories, which also reflected their formation, was that proposed by the German geologist Abraham Gottlob Werner (1750-1817). He recognized four classes of rock masses or Gebirgsarten: Uranfängliche or primitive rocks which were mainly of igneous and metamorphic origin and included basalt; Flötz or stratified sedimentary rocks, often containing fossils; Vulkanische or volcanic rocks; and Aufgeschwemmte or alluvial sediments (Werner 1786). Werner believed in an aqueous origin of crystalline rocks, including basalt, the Neptunist view, which had been precipitated from solution in a sea that initially covered the entire globe. As the sea level fell over time, 


\section{WOLF MAYER}

part of the basement of primitive rocks became exposed to a greater or lesser extent. Debris produced by erosion of the emerging land resulted in the deposition of often fossil-bearing sedimentary layers. The denudation of both primitive and stratified rocks contributed to form a localised cover of alluvium. Volcanic eruptions resulted in "true volcanic rocks", which covered areas of limited extent, while rocks merely altered by fire, probably always coal formations, were recognized as "pseudo-volcanic rocks" (Werner 1786, p. 292; Ospovat 1971; Seddon 1973).

Dolomieu, Depuch's teacher at the École des mines, taught a four-fold scheme of rock classification, which partly mirrored that proposed by Werner. The lecture notes taken by one of his students ${ }^{2}$ record it as follows:

Terrains of precipitation: the result of crystallization following a process of dissolution. This has led to the formation of primitive or primordial rocks of which the granites are the most important products.

Sedimentary terrains: which have formed more or less parallel beds and which are classified as rocks of the second type. In contrast to the primitive rocks, these rocks enclose organic bodies which are unquestionably of marine origin.

Terrains of transport: formed from the debris of the first two terrains, carried along by waters, and resulting in the deposition of alluvium.

Volcanic terrains: composed of material ejected from within the Earth and piled up on top of one another by the action of subterranean fires.

Dolomieu accepted Werner's Neptunist teaching on the origin of crystalline rocks, such as granites. However, his views diverged from those of his German colleague with regard to the formation and the areal extent of volcanic rocks. His own investigations, particularly in France and Italy (Dolomieu 1794a, b), convinced him that such rocks had a wide distribution and that basalt was a product of volcanic activity. Dolomieu was planning to travel to Freiberg late in 1801 to present Werner with evidence that supported the volcanic origin of basalt and, as Touret (2005, p. 135) put it: "no doubt to try to reconcile Plutonists and Neptunists", at least as far as the basalt controversy was concerned. Unfortunately, before he could set out on his journey, Dolomieu fell ill and died in November of that year. We can only speculate as to the likelihood of his success in convincing Werner to alter his firmly held beliefs.

The Plutonist views expressed by Hutton (1795) were not mentioned by Dolomieu in his 1796 lecture course, and the naturalists taking part in the expedition to Australia seem to have been unaware of them. Hutton's major work is not listed among the books carried in the libraries of the two ships (Bonnemains et al. 2001, pp. 90-95).

When describing and ordering Australian rocks, Depuch largely applied the classification taught to him by Dolomieu. To what extent Bailly's use of the same scheme was based on knowledge he had acquired independently or reflected the views of Depuch, his senior colleague, is uncertain. Péron, who appears to have learned much about geology from Depuch, also used Dolomieu's classification in his own investigations, but augmented it by applying the term 'tertiary' to two separate occurrences of sedimentary rocks. He was familiar with the work of Horace Bénédict de Saussure (1740-1799), who had recognized "tertiary mountains" in the European Alps composed of the debris derived from those of the primitive and secondary kind (Saussure 1779, p. 496).

Based broadly on Dolomieu's scheme of classification, the naturalists included all rocks they deemed to be 'granite', as well as metamorphic rocks and deformed sedimentary

Cordier, L. 1796. Extrait des leçons orales faites par Dolomieu, sur le gisement des minéraux, au commencement de 1796 à l'École des Mines de Paris. Rédigé par moi, alors que j'étais élève des mines et obligé de justifier de mon travail à chaque professeur. Archives de l'Académie des sciences, Paris, 4J 16. See: http://www.musee.ensmp.fr/dolomieu. 
strata, in the category of the Primitive. These they regarded as the first-formed and oldest rocks in any particular region. Sedimentary rocks forming regular horizontal layers, often containing organic matter, they generally assigned to the Secondary. All loose sedimentary material covering the surface of the land, but also lightly consolidated stratified sediment with or without organic matter, as well as dune deposits, they considered to be part of the Alluvium. Only with respect to the identification of 'volcanic rocks' were there differences of opinion among them.

In the following four sections the discussion of the geological discoveries made by members of the expedition is based broadly on the sequence in Dolomieu's scheme of rock classification, rather than the chronological order of the voyages' progress.

\section{THE 'GRANITES'}

\subsection{Geographe Bay}

In late May 1801, some days after sighting the coast near the Australian continent's southwestern tip, the expedition's two ships entered a large bay, which Baudin named Baie $d u$ Géographe (Geographe Bay) after his flag ship (see Figure 2). From their first anchorage the captain dispatched a small boat under the command of Lieutenant Henri Freycinet (1777-1840), the older brother of Louis, to reconnoiter a part of the country not previously visited by Europeans. From the 'scientific' personnel under his command Baudin chose his senior mineralogist, Louis Depuch, and his head gardener, Anselme Riedlé (?-1801), "the one to give us an idea of the country and the other to discover the nature of the soil" (Baudin 2004, p. 164).

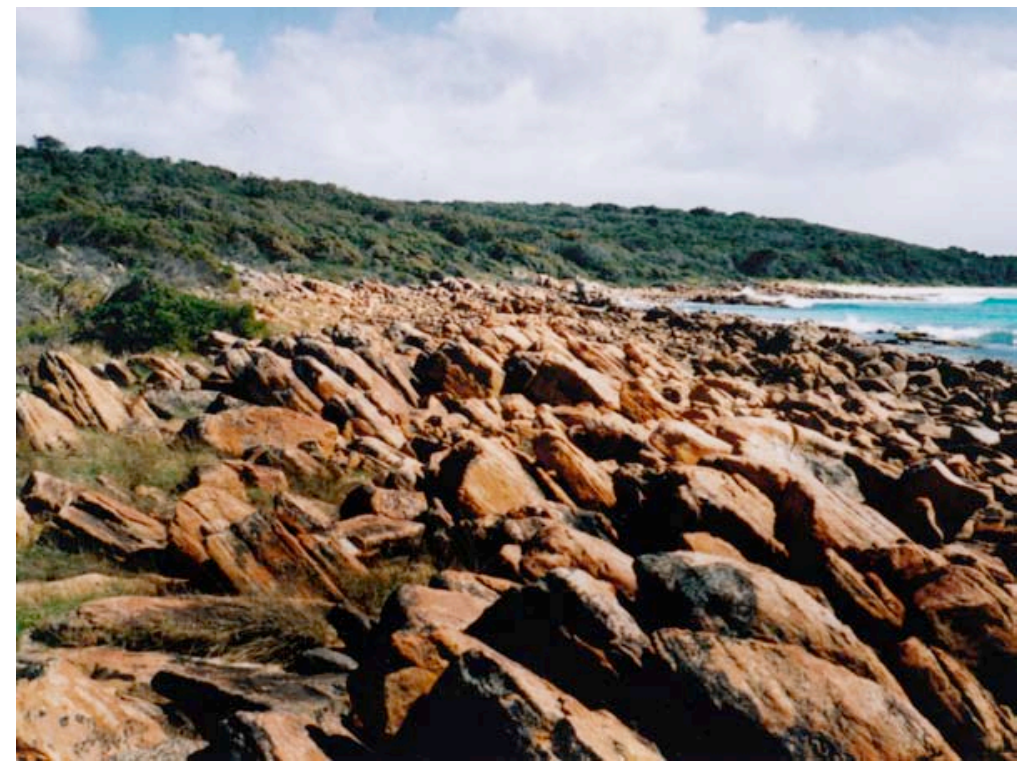

Figure 4.

Depuch's 'stratified granite', being outcrops of Precambrian granitegneiss at Eagle Bay (Anse Depuch), Western Australia.

Depuch recognized extensive outcrops of 'granite' on both sides of the little cove where he landed (see Figure 4). He described these rocks as being composed of feldspar, which often predominated, transparent quartz and brilliant black mica occurring in strips or bands. The presence of both well-developed and regularly spaced joint planes in these rocks and the fact that its component minerals seemed to form distinct layers parallel to these planes, suggested to Depuch the presence of stratification (Baudin 2004, p. 167). This 
observations reminded him of the claim made earlier by de Saussure (1779, pp. 99-100) that granites in the European Alps were stratified and occurred in beds of more or less equal thickness, and led him to state that "it is impossible not to be convinced here of the fact, which Mr. de Saussure was the first to recognise and which several naturalists still contest, that granites are apt to stratify" (Baudin 2004, p. 167).

In his catalogue of rock and mineral specimens, Bailly confirmed the presence of compositional banding in Depuch's rock samples and noted further that "the mica is here arranged in beds and stratified, with white quartz also forming beds although less thick than those made of black mica". ${ }^{3}$ As he had not himself seen the outcrops in the field, it is somewhat puzzling why he reached the conclusion "that the granite has been formed in a fissure where water will have deposited its constituent parts". It is likely that Bailly based this interpretation on information he had gleaned from the writings of de Saussure who, after early hesitation, came to share Werner's Neptunist views and who, possibly referring to a series of pegmatite veins in the European Alps, had remarked that these granites "will have formed in fissures by the infiltration of water" (Saussure 1779, p. 533).

Baudin, having accepted that Depuch's discovery was of scientific significance, named this first landing place Anse granite or Granite Cove. ${ }^{4}$ However, Péron and Freycinet (2006, p. 61), who also recognised that "this remarkable phenomenon" recorded by Depuch was of special interest to science, "thought it fitting to give it the name of the naturalist who was the first to see and describe it" and renamed it Anse Depuch. Today it is commonly known as Eagle Bay, although on topographic maps of the region the original French name is added in brackets.

The German geologist Leopold von Buch (1774-1853), who in 1810 examined Depuch's 'granite' specimens in Paris, identified them as gneiss (von Buch 1814, p. 236). Recent geological maps show these outcrops as granite-gneiss of Precambrian age (Lowry 1967, p. 5).

It is interesting to note here that Depuch appears to have anticipated the finding of granite on shore. The day before the landing, Baudin had the sea floor around his anchorage dredged for sediment samples. The drag brought up sand mixed with a black mud containing shiny particles of mica. Baudin recorded their conclusion that the mineral flakes represented "fragments of granite which the action of time and rain had broken up and swept out into the sea" (Bonnemains et al. 2001, p. 223). It is likely that this collective view was based on the informed opinion of Depuch.

\subsection{Tasmania}

When, some eight months later, the expedition's naturalists had their next opportunity to examine outcrops of granitic rocks along the eastern coast of Tasmania, Depuch was ill and no longer able to play a major role in geological surveying. From here on the zoologist, François Péron, took on the added duties as the Géographe's 'acting mineralogist'.

Between January and March 1802 the two ships surveyed the eastern and northern coasts of Tasmania (see Figure 2), giving both Bailly and Péron ample opportunity to study and record aspects of the local geology. Péron, when surveying Maria Island, applied the term 'granite' to both genuine granitic rocks (now regarded as being of Late to Middle

Bailly, C. 1801-1803. Catalogue des substances minérales recueillies pendant le voyage de découvertes commandé par le Capitaine Baudin (transcription by Madame R. Helouis, 1913). Service hydrographique de la Marine, Carton 22/23, 4-81; Mitchell Library, Sydney, Manuscript Collection, ML B1265, CY Reel 4346.

Journal de mer et table des loch de Ronsard, officier du génie maritime et lieutenant de vaisseau sur le Géographe (ans IX-XI). Archives nationales, Paris, 5JJ28-30; National Library of Australia, Canberra, G 2164 (Reel 10), pp. 61-62. 
Devonian age) as well as to some outcrops of dolerite (now regarded as Jurassic). Outcrops of the former (see Figure 5), he described as "remarkable for its large crystals of yellowish feldspar and greenish colour of the mica which, with quartz, is interposed between the crystals", while he recorded the latter as "dark green and fine grained" rocks (see Figure 6) (Péron and Freycinet 2006, p. 235). Tasmanian dolerite is usually blue-grey when fresh (John Everard, pers. com.).

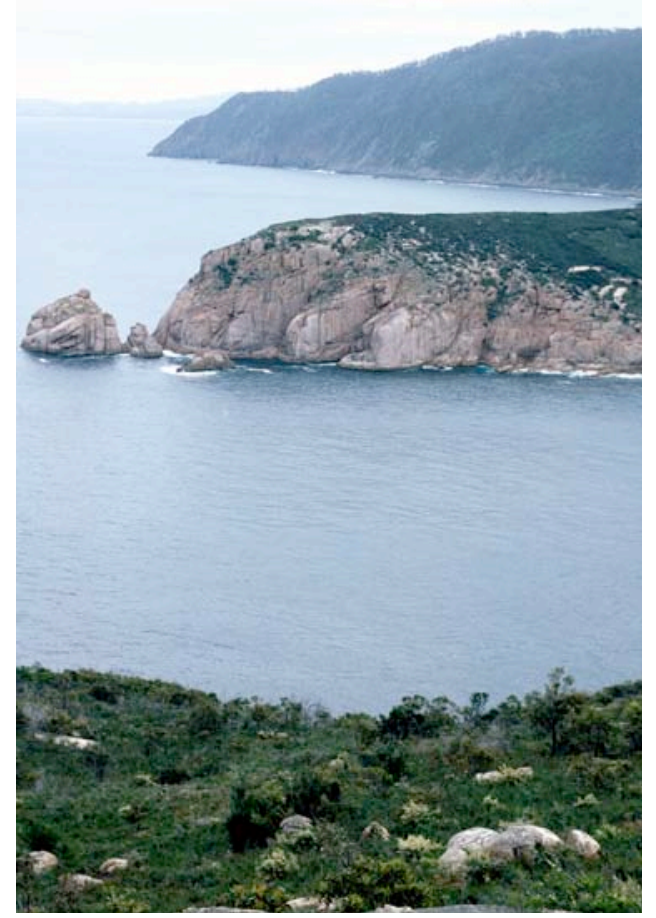

Figure 5. Granite on Maria Island, off the east coast of Tasmania (today regarded as Late to Middle Devonian). The coarse grain size of these rocks suggested to Depuch that they were the oldest they had found in Australia. Photo by courtesy of the Department of Mineral Resources, Hobart, Tasmania.

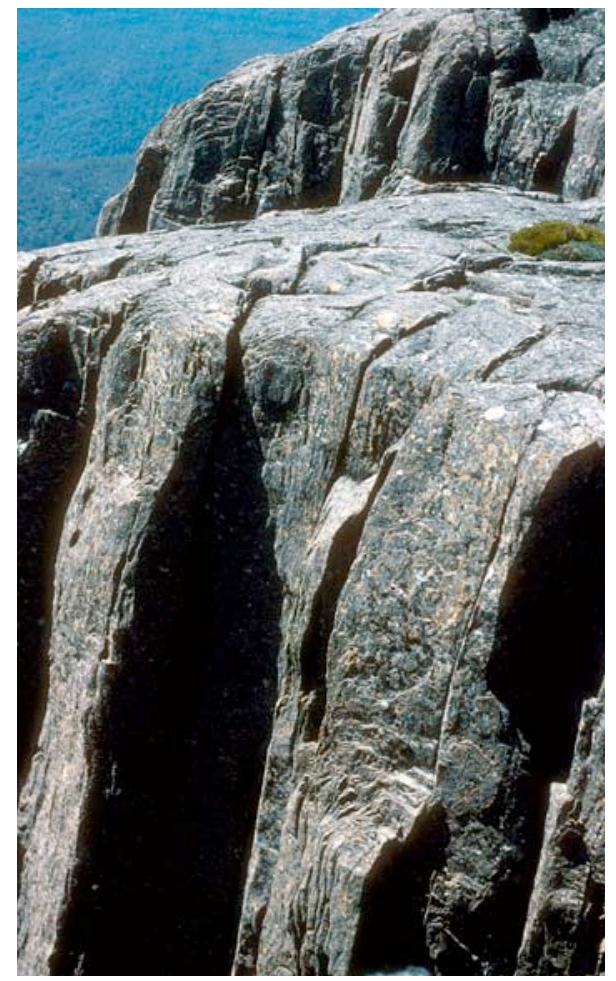

Figure 6. Outcrops of Jurassic dolerite in northeastern Tasmania. Similar rocks were identified by Péron as granite on Maria Island and by Bailly as lava or basalt along the Tasmanian coast. Photo by courtesy of the Department of Mineral Resources, Hobart, Tasmania.

Bailly, working independently of Péron, did not employ his colleague's wider definition of 'granite' but used the term mostly for rocks of genuine granitic composition of Devonian age which he observed on Tasmania's eastern coast and its adjacent islands. In these specimens he also identified the minerals quartz, feldspar and mica and noted their relative abundance. From the vicinity of Port Cygnet, in Tasmania's south east, he recorded 'granite' containing large crystals of feldspar, needles of amphibole and rare tourmaline, which may have come from outcrops or, more likely, from pebbles of Cretaceous syenite. ${ }^{5}$

Both Bailly and Péron concluded that the respective rock types they had identified as 'granite' in Tasmania belonged to the category of the Primitive. After examining one of Péron's specimens from Maria Island that contained feldspar crystals up to four centimetres in length, Depuch declared this granite to be "the most beautiful of all that have offered themselves for examination in this part of the world". Perhaps recalling the words of

5 Bailly, Catalogue, 23-77. (See note 3.) 
Dolomieu that rocks containing larger crystals were the first to form, ${ }^{6}$ he declared that this specimen represented "the oldest of all the rocks" they had seen in this region (von Buch 1814, p. 239). Péron, probably after comparing his own samples with those from Bailly's collection during the stop-over of the two ships at Sydney, observed correctly that the coarse grained granites found by himself on Maria Island and those collected by Bailly at the Freycinet Peninsula, further to the north, were of the same composition (Péron 1807, pp. 299-300).

The most notable absence in the naturalists' descriptions of Tasmanian 'granites' is any reference to stratification. Both Bailly and Péron had readily accepted Depuch's earlier conclusion that the 'granites' cropping out at Geographe Bay formed distinct layers. While the finding of "veins or seams of black mica" in granites on Freycinet Peninsula, reminded Bailly of the foliated rocks from the continent's western coast, ${ }^{7}$ neither he nor his colleagues made any further references to this topic. Nevertheless, the second edition of the Voyage, published more than twenty years later, still refers to Depuch's discovery of "a very beautiful type of granite, forming very many regular layers" (Péron and Freycinet 2006, p. $61)$.

\subsection{Blue Mountains, New South Wales}

The sojourn of the Baudin expedition at Sydney of about five months, from June to November 1802, allowed its exhausted crew much needed rest. Depuch's health improved sufficiently to allow him to undertake an excursion to the foot of the Blue Mountains in the company of Bailly, the only occasion during the voyage when the two mineralogists worked together in the field. Unfortunately, this cooperative effort led Bailly to cease describing the rock specimens they had collected in his own catalogue, leaving this task to his senior colleague, whose journals are now lost. ${ }^{8}$ Bailly did, however, write a detailed account of their week-long journey (Péron and Freycinet 2006, pp. 339-347).

As they approached the higher ground, following their traverse of the Triassic sedimentary sequence of the Sydney Basin, the two mineralogists noted increasing amounts of pebbles of igneous rocks in the bed of the Hawkesbury River (Mayer 2007, p. 333). Reflecting the view of Dolomieu, they concluded that these coarsely crystalline rocks, including specimens of granite, made up the Primitive core of the mountain range that rose before them. ${ }^{9}$

\subsection{The southern Australian coast}

Péron, when studying the geology of the island of St Peter and of the adjacent mainland along the coast of southern Australia (see Figure 2) during the expedition's return voyage in 1803, described several kinds of 'granite', all of which "consist of feldspar, which forms the base, quartz and mica". One type of these rocks he described simply as 'foliated granite', whereas in a second type he noted "oblique, winding, black lines" formed by the alignment of black mica (see Figure 7). He was referring to specimens of what are now regarded as Palaeo- and Mesoproterozoic gneiss and granitic rocks, which crop out along this coast and on some of its near-shore islands (Rankin and Flint 1991, Drexel and Preiss 1995). 


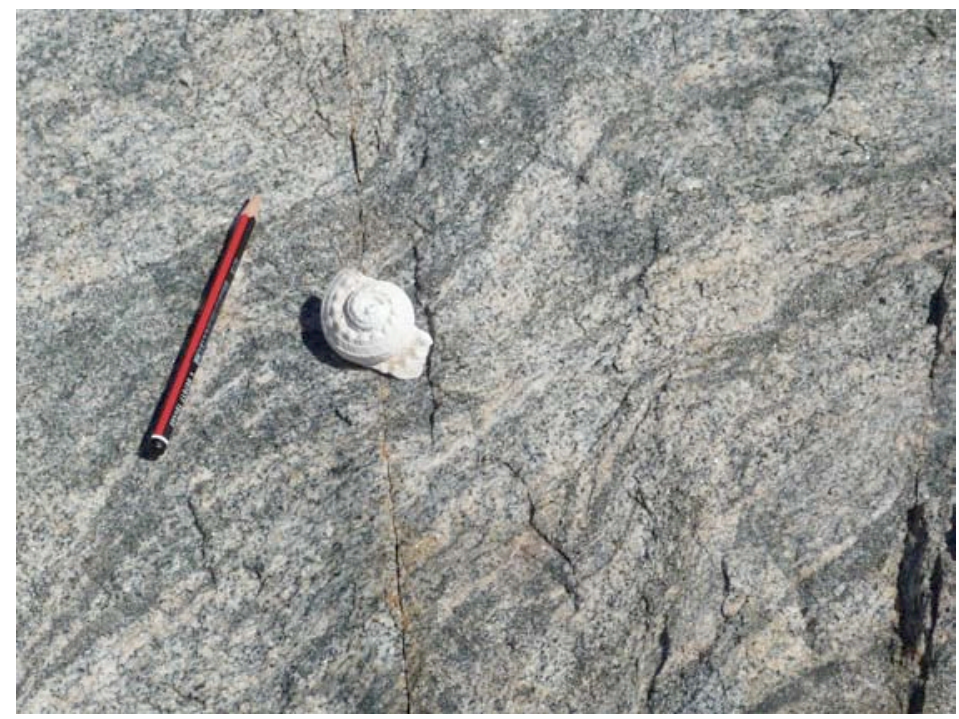

Figure 7.

Palaeoproterozoic granitegneiss cropping out at Rocky Point, west of Ceduna, in South Australia. Péron noted the "oblique, winding black lines formed by black mica" and identified the rock as granite.

Close to the western extremity of the continent's southern coast Bailly, now Péron's companion on the Géographe, found "a type of granite, full of garnets, some of which were the size of the little finger" (Péron and Freycinet 2003, p. 108). He was most likely referring to the Proterozoic garnet-bearing augen gneiss which crops out in King George Sound at the entrance to Oyster Harbour. Von Buch (1814, p. 236), who examined this specimen in Paris, identified quartz intergrown with feldspar and described it as a graphic granite. More recent examination shows antiperthitic intergrowth of alkali feldspar in plagioclase (Muhling and Brakel 1985, p. 7).

\subsection{General conclusions}

After observing outcrops of rocks along large stretches of Australia's coastline and examining many specimens collected by himself and his colleagues, Péron expressed the opinion that the terrain from Tasmania to Western Australia, including the many islands along these parts of the continent, is "basically primitive". He agreed with the views of Depuch and Bailly that "granites form the base and foundation of all the terrain" and, although the basement rocks were often overlain by younger strata belonging to the Secondary category, he considered that, in comparison with the extent of the Primitive rocks, these formed a lesser part of the geology (Péron and Freycinet 2003, p. 91).

\section{THE SEDIMENTARY ROCKS}

\subsection{The western Australian coast}

Soon after leaving Geographe Bay in June 1801, the expedition's two ships became separated and did not meet up again until they reached Timor in September of that year. On their way north they sailed independently along a low-lying coastline where outcrops of horizontally layered sedimentary rocks, usually capped by dune sands, form the western margin of the Australian continent for hundreds of kilometres of its length. These stratified sedimentary rocks are known today as the Tamala Limestone of Pleistocene to Early Holocene age (see Figure 8), a largely aeolian sequence of calcareous sediments, containing marine intercalations (Playford et al. 1976; Playford 1988; Kendrick et al. 1991). Bailly studied these deposits in outcrops along the Swan River, on Rottnest Island and at Shark 


\section{WOLF MAYER}

Bay, while Depuch and Péron examined the same formation mainly at Shark Bay (see Figure 2). At the latter location the two parties fortuitously investigated separate sections of the same sequence.

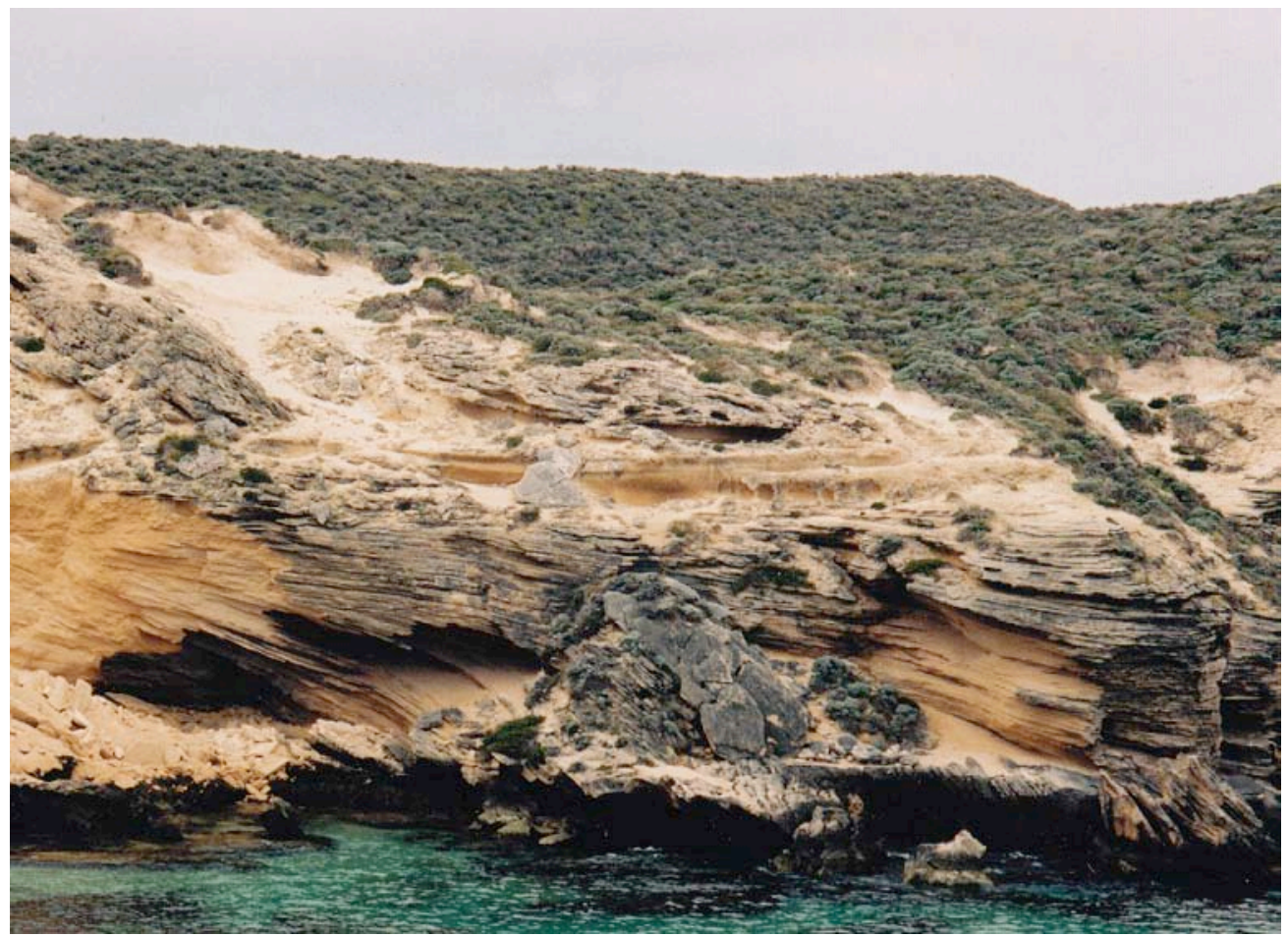

Figure 8. Tamala Limestone in an outcrop on Rottnest Island, Western Australia. The Expedition's naturalists regarded these rocks as being part of the Secondary formation, overlying a basement composed of granite. This rock is today regarded as being of Pleistocene age.

Baudin's investigators were unanimous in assigning these calcareous sedimentary rocks to the category of the Secondary and agreed that they represented marine deposits overlying a basement composed of the Primitive granitic rocks that they had encountered during their earlier investigations at Geographe Bay (see Figure 4). They recognised that the strata extended continuously over vast distances along the western coast of the continent and that many of its layers contained fossils. The finding of petrified tree trunks and roots in some of the beds, and the presence of mollusks on the beaches similar in appearance to those embedded in the nearby outcrops, satisfied them that these rocks were of a young age and had only in recent times emerged as dry land (Péron and Freycinet 2006, pp. 92, 142 146). ${ }^{10}$ (For a more detailed account of their investigations of the Tamala Limestone, see Mayer 2008).

\subsection{The Sydney Basin}

Since the start of European settlement at Sydney Cove in 1788, the rock formations cropping out in its vicinity had been examined by a number of the colony's military officers

10 Bailly, C. 1801. Observations minéralogiques et géologiques fait dans la Rivière des Cygnes, juin 17-22, 1801. Service hydrographique de la Marine, Carton 12; Mitchell Library Sydney, Manuscript Collection, Baudin Papers, Vol. 18, B1278, pp. 97-99. 
and other officials, mainly in the search for limestone to obtain lime for making mortar (Mayer 2007). Depuch and Bailly were the first professional geologists to survey parts of the sedimentary sequence of the Sydney Basin and to provide detailed descriptions of its rocks.

The two investigators noted that the region surrounding Sydney, and extending to the foothills of the Blue Mountains, was mainly formed of horizontal layers of sandstone, including occasional conglomerates and shaly rocks-Bailly referred to the latter as schist - which in the region they visited tended to make up the upper parts of the outcrops. They were also aware that this sequence of rocks, which they regarded as belonging to the Secondary formation, provided a cover over the Primitive granitic core of the Blue Mountains. These rocks of the Sydney Basin sequence are now recognized, respectively, as the Hawkesbury Sandstone and the shale-rich Wianamatta Group, both of Triassic age (Herbert and Helby 1980).

The travellers noted that individual beds ranged from barely a few millimetres to several metres in thickness, that the sandstone was mainly composed of quartz and that the shales contained imprints of plants, "noticeably those of various kinds of fern". At the foot of the Blue Mountains, at the confluence of the Hawkesbury and the Grose River, they "found large deposits of bituminous schist which burns with a bright flame" (Péron and Freycinet 2006, pp. 339-347). As has been noted elsewhere (Carne 1903, p. 1), this is the first reference to oil shale in Australia, and predates the discoveries at Torbane Hill in Scotland by some fifty years. However, as no outcrops of oil shale occur at the site from which they reported their find, it must be assumed that their 'deposits' consisted of nests of pebbles and boulders eroded from outcrops now known to occur higher up in the mountains. The two mineralogists were aware of major coal seams cropping out along parts of the New South Wales coast, both to the north and the south of Sydney, "situated at the earth's surface and spreading in all possible directions". Following their own observations of the local geology a short distance inland from Sydney, Bailly wrote that: "to judge by analogy and from the numerous indications presented by the composition of the terrain, one could state positively that there is a great quantity of coal beneath the very soil of Parramatta" (Péron and Freycinet 2006, p. 340). Their assumption that the coal seams cropping out to the north continued beneath the ground to Parramatta and extended further to reappear in southern outcrops, suggests that they contemplated the existence of a sedimentary basin. While the surgeon/explorer George Bass (1771-1803) had hinted at the presence of a basin structure in 1797 (Vallance 1975, p. 30), the implied inference of the Frenchmen was based on firmer grounds.

\subsection{Tasmania}

During his circumnavigation of Maria Island in a small boat, Péron observed outcrops of two types of sandstone of very different appearance. The first of these he described as "very fine grained, compact, and of a homogeneous texture, whitish and sparkling" (Péron and Freycinet 2006, pp. 235; Plomley et al. 1990, p. 37), and in one of his manuscript versions ${ }^{11}$ he referred to an outcrop of these same strata as couches en zig-zag or zig-zag beds, implying that they were folded. He concluded that these deformed rocks must be of an older formation than the horizontal strata he had previously examined and therefore must belong to the Primitive. Banks (in Plomley et al. 1990, p. 37) tends to the view that Péron was

11 Péron, F. 1802. Topographie générale de l’Ile Maria sur la côte Orientale de la Terre de Diémen, Observations Minérales et Géologiques. Collection Lesueur, Muséum d'histoire naturelle du Havre, MS 08040; National Library of Australia, Canberra, MS 2187 (Reel 33), p. 57. 
describing the deformed strata of the Mathinna Beds, probably of Early Devonian age, cropping out on Maria Island's east coast.

The second type of sedimentary rocks he encountered formed very regular, horizontal layers, which he described as "loose-textured, friable and very calcareous", the origin of which "must apparently be attributed to a long succession of shelly deposits" (Péron and Freycinet 2006, p. 235). He confidently interpreted these strata as marine deposits and placed them in the category of the Secondary. Banks (Plomley et al. p. 37) has suggested that the 'secondary sandstone' seen by Péron forms part of the Permian and Triassic succession on the island, which includes calcareous layers. In one of his manuscripts, but not in his official publication, Péron referred to a specimen of calcareous sandstone derived from a sequence of horizontal beds as being "manifestly tertiary in origin". ${ }^{12} \mathrm{He}$ did not explain in what respect this rock differed from others he had included in his category of the Secondary.

\subsection{Kangaroo Island and the continent's southern coast}

On its return voyage, in early 1803, the Géographe spent several weeks near Kangaroo Island (see Figure 2), where Péron was again confronted by two vastly different sequences of layered rocks. The outcrops of schist, containing veins of opaque quartz, and the quartzose, very dense sandstone he observed there, and which he regarded as part of the Primitive, equate almost certainly with interbedded phyllites, schists and meta-sandstones of Cambrian age, which crop out along the southern shore of Nepean Bay, and elsewhere on the island. At several localities on Kangaroo Island, and later on the island of St Peter and the adjacent mainland, he also noted deposits of "limestone . . some similar to sandstone, others more like chalk", which variously contained shell debris and the remains of petrified trees, "at times so numerous as to give the impression of a petrified forest" (Péron and Freycinet 2003, pp. 60-61, 91-93). These deposits—part of Péron's Secondary-are represented by Pleistocene aeolian quartz sands and calcarenites, limestone, calcrete and soil horizons, the latter containing the root casts of trees. Péron took a particular interest in the process he referred to as encrustation or petrifaction, relating to the preservation of organic matter and the cementation of sediments (Péron 2007, pp. 36-40). This topic is discussed in more detail in Mayer (2008, pp. 284-285).

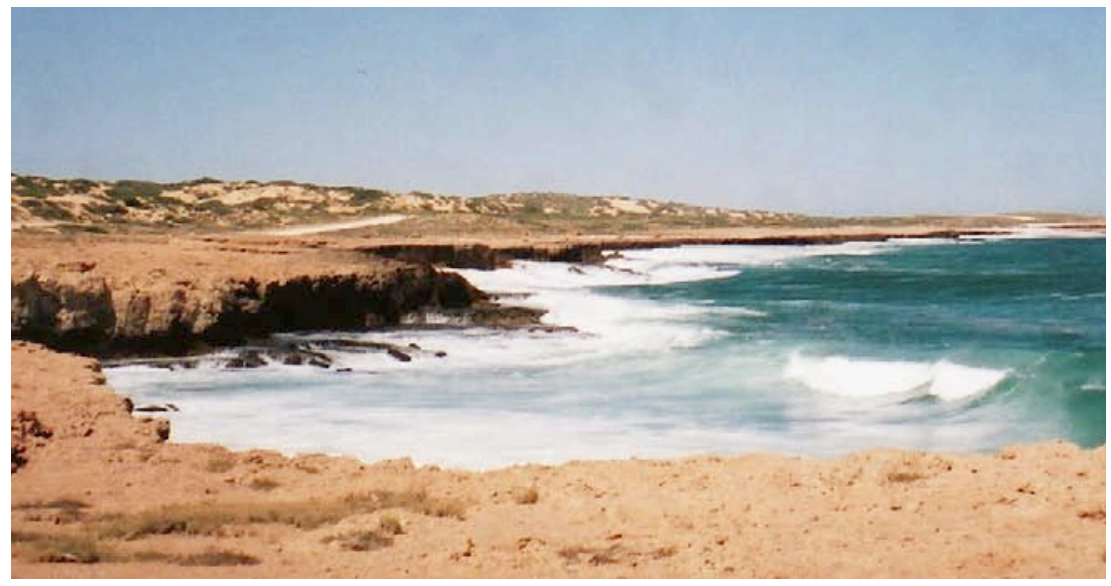

Figure 9 . Shore platform of Pleistocene rocks overlain by sand dunes, north of Carnavon, Western Australia.

Péron, F. 1802. Topographie générale de l'Ile Maria sur la côte Orientale de la Terre de Diémen, Observations géologiques. Collection Lesueur, Muséum d'histoire naturelle du Havre, MS 18043, p. 16; National Library of Australia, Canberra, MS 2187 (Reel 33). 


\section{ALLUVIUM AND SAND DUNES}

The French explorers used the term 'Alluvium' in a much broader sense than current practice dictates; they included under this heading all loose and even some lightly consolidated sediment, regardless of its origin. They were greatly impressed by the widespread extent of Quaternary to Recent deposits of quartz sand, often containing shell debris, that border much of Australia's coastlines (see Figure 9 on previous page) and, at some localities, also form part of the plains that lie behind them.

When anchored in Geographe Bay, Baudin, glancing towards its shores, observed that "as far as the eye could see, the coast was bordered by sand-dunes", and declared that "all the dunes looked to me to be the work of the sea, which carries the sand, and of the wind, which piles it up and moves it a certain distance in the course of time" (Baudin 2004, p. 174). Péron, who had surveyed these coastal dunes and parts of the large expanse of lowlying land behind them, largely agreed with his captain:

All of the beach, all the dunes, even the most elevated, all the terrain beyond, which I have been able to traverse, are essentially formed by quartzose sand, mostly whitish and pure, sometimes blackish. Very rarely, does one find shells and corals mixed with the debris. Being of the same nature as the sediment which has been brought up from the bottom of the sea by the lead line, it seems clear that the sand was deposited by waters, which then undoubtedly covered this beach, and which was then left there to dry by the imperceptible retreat of this sea. There is no trace of calcareous material, which rather rules out any idea of a secondary origin (Bonnemains et al. 2001, p. 253).

Péron deserves credit for his early application of uniformitarian principles in arguing from the present to explain the past. In so far as marine intercalations are present in this largely aeolian sequence of deposits, he was partly correct in his interpretation. However, his criterion for recognising rocks of secondary origin was not shared by his colleagues; indeed, Péron himself did not seem to adhere to it when describing rocks he recognized as part of the Secondary at other localities. While, like his captain, Péron could not envisage wind action as being the primary agent in the formation of dunes, his later observations along the continent's southern coast convinced him that wind played a role in the movement of the sands, subsequent to its deposition by the sea:

On top of the various sandstones and granites that I have just described, lies a more or less thick layer of very fine, white, grey or even reddish sand. At several points it forms rows of high dunes and sometimes it has carried inland and covers bushes and even the tallest trees with its shifting waves. Péron and Freycinet 2003, pp. 91-93).

Depuch, who examined an area adjacent to that seen by Péron, formed the opinion that all the higher ground surrounding Geographe Bay was composed of the granitic rocks he had earlier discovered on its southern shore and formed the basement on which the 'alluvial' sediments had been deposited. He also suggested that the sediments of both the dunes and the plains may have been deposited by a transgression of the sea, but added the alternative possibility that their formation may be the result of rivers carrying debris from the continent's interior. His finding of marine shells in lightly cemented sands on the inland side of the coastal dunes, together with the presence of shell debris on the surface of the ground, persuaded him to the view that marine influences played a dominant, perhaps the sole, role in the deposition of these sediments and led him to favour the idea that the formation of all the flat, sandy terrain he had surveyed was the result of "the never-ending action of the sea". Like his colleagues, Depuch's field observations left him in no doubt that, 


\section{WOLF MAYER}

once established, dunes were not static and that wind-induced movement of the sand altered their shapes (Bonnemains et al. 2001, pp. 247-249).

Depuch also noted the presence of what he suspected to be metallic particles in the sand deposits at Geographe Bay. Together with Péron's mention of blackish sands, this is the first, albeit imprecise, reference to the heavy mineral deposits occurring along parts of the south western coast of Western Australia, which would not be exploited for another 150 years. $^{13}$

The naturalists had been correct in stating that most of the sediments they examined at Geographe Bay had been transported to their place of deposition from the seaward side of the coast. However, their unfamiliarity with large-scale aeolian processes in the formation of sedimentary deposits (Mayer 2008) led them to assume that these Quaternary and Recent sediments were carried inland by a transgressing sea. While they were aware that the building up of complex geological sequences required multiple transgression, they believed that one major invasion of the sea accounted for the deposition of all the sediments that today form the coastal lowlands around Geographe Bay.

The explanations offered by Depuch regarding the processes of sedimentation in and around Geographe Bay closely reflect the views of Dolomieu. The latter distinguished between two vastly different modes of deposition of Alluvium. The first, largely based on field observation, expressed the now conventional view of the movement of sand and mud along riverbeds, leading to their eventual deposition both on land and in the sea. However, Dolomieu did not believe that large accumulations of boulders and associated sediments- "sometimes covering immense plains", and often derived from rocks of a distant provenance - could have been moved by ordinary river currents. Instead, he proposed that periodic, violent upheavals, possibly caused by an approaching comet, created tidal waves of immense height and force which could pick up and carry debris over long distances and deposit it over wide areas. ${ }^{14}$ In following his former teacher's views, Depuch accepted, on the one hand, that sediment now at the bottom of Geographe Bay was carried into the sea by rivers while, on the other hand, the dune sands, often covered by shell debris and the partly fossiliferous sediments of the plain behind them, represented sediment left behind by one of the "great tides" and formed part of the Alluvium (Bonnemains et al. 2001, pp. 247-248).

\section{THE 'VOLCANIC ROCKS'}

The expedition's naturalists were given the opportunity to make detailed studies of volcanic rocks on their outward voyage, at both Tenerife and the Ile de France (Mauritius) (Bailly $1812,1825)$. Their seemingly unnecessary concluding remarks in many of their geological reports, that they had not found any volcanic rocks, seem to suggest that they had high expectations of also making such discoveries in Australia.

\subsection{Depuch Island}

In late July 1801, as the Géographe sailed along the continent's north western coast, the ship's crew sighted an island, later named Depuch Island (see Figure 2), which by its greater elevation, darker colour and more abundant vegetation cover, was in stark contrast to the monotony of the mostly low-lying, almost barren coast they had hitherto observed. It seemed most promising ground for the naturalists to explore and all were eager to go ashore.

\footnotetext{
13 Depuch, L. 1801. Rapport fait au commandant sur l'état géologique de la baie du Géographe, le 26 prairial an IX [15 June 1801] (transcribed by Jacqueline Bonnemains). Collection Lesueur, Muséum

14 Cordier, Extrait des leçons, 31-37. (See note 2.)
} 
Unfortunately, the captain, who had been much angered by the repeated disregard to his orders by some of the naturalists when ashore, refused them permission to leave the ship and instead sent his naval engineer, François M. Ronsard (1769-18?), to investigate.

Ronsard returned the next day with the news that "the island's terrain is completely composed of a mass of prisms of basalt heaped on top of each other" and that "frequently, and particularly towards the top of the peaks [the top of the cliffs], they were standing on one of their small sides" [in a vertical position] (Bonnemains et al. 2001, p. 306). In his private journal he referred to these columns as pentahedrons which "generally rest on their angles". He also noted that eroded basalt columns formed a pavement along parts of the island's shore and that the rocks "are covered in iron-oxide which gives a red-brown colour to the whole island". ${ }^{15}$

The officer gave a more detailed verbal account of his discoveries to Depuch and presented him with some specimens of the 'basalt'. On the basis of this information the mineralogist was able to state that the rocks displayed a columnar structure, "in the manner common to these products of subterranean fire". He commented further that the columns were made up of three-, four- and five-sided prisms and formed a type of natural pavement along the island's shore. The specimens were grey in colour tending to blue, of fine grain and had the appearance of petrosilex with a dense texture. Dolomieu had taught that petrosilex was predominantly composed of fine-grained feldspar, although quartz was present in its less pure form (Cordier 1796, p. 11). Depuch also noted shiny laths, probably feldspar, which was distributed irregularly throughout the rock. The 'basalt' did not effervesce when tested with acids and did not noticeably react to the bar magnet. Its outer surface had been subjected to a kind of weathering or alteration produced by iron molecules, normally to a depth of three or four millimetres, sometimes more but more often less.

The information he had been given by Ronsard convinced Depuch that "the island's terrain was entirely of a volcanic nature". ${ }^{16}$ Péron declared that "the volcanic nature of Depuch Island ensures its quite particular importance", and though not having seen the outcrops himself he talked up the discovery by comparing the 'basaltic' pavement on the island to that of the Giant's Causeway in Northern Ireland (Péron and Freycinet 2006, p. 107). The explorers would no doubt have been amazed to learn that they had examined Archaean meta-dolerite, more than 2,925 million years old (Hickman and Smithies 2001, p. 29 ), the oldest rocks that they would encounter on the voyage. Ronsard interestingly commented that the rocks forming the hills on the nearby mainland seemed to be of similar composition to those on Depuch Island. Had the naturalists been able to land there, they might have found the first evidence of volcanic activity in Australia in the form of Archaean meta-basalts, which crop out some ten kilometres inland.

Significantly, Ronsard used both of the terms 'basalt' and 'lava' to describe the rocks he had found on Depuch Island. The naval officer, like his scientifically educated colleagues, clearly accepted basalt as a product of volcanic eruptions. The assumed discovery of 'volcanic rocks' in Australia, allowed Depuch to claim that they had now found every one of Dolomieu's "four types of terrain that make up the entire exterior part of the globe". ${ }^{17}$

\subsection{Tasmania}

When referring to the 'volcanic' rocks of Depuch Island, Péron, stated that they did not again "come upon anything of that kind". It is curious, then, to note his later description of

\footnotetext{
15 Ronsard, Journal de mer, 68-69. (See note 4.)

16 Depuch, L. 1801. Quelques observations sur l'Ile des Amiraux (transcribed by Jacqueline Bonnemains). Collection Lesueur, Muséum d'histoire naturelle du Havre, MS 08015, pp. 1-3.

17 Depuch, Quelques observations, 3. (See note 16.)
} 
"pebbles of basaltic rock" from the banks of the Derwent River (possibly at Sandy Bay, near Hobart; Max Banks, pers. com.), and his reference to the role of volcanic fires in shaping the island of Tasmania (Péron and Freycinet 2006, p. 107). When observing the columnar cliff exposures of the "great Plateau Mountain", today's Mount Wellington near Hobart, he described them more tentatively as "resembling volcanic ramparts", or as "prisms and needles of basaltic appearance" in the case of cliff exposures along the south eastern coast of Tasmania (see Figure 10). The sight of the spectacular columns forming Cape Haüy, on Tasmania's east coast, evoked an image of "immense organ pipes resting on the water's surface" (Péron and Freycinet 2006, p. 196, 207). In all cases, the rocks he had observed are now known to be dolerites of Jurassic age. As stated above, on Maria Island Péron identified some outcrops of dolerite as granite.

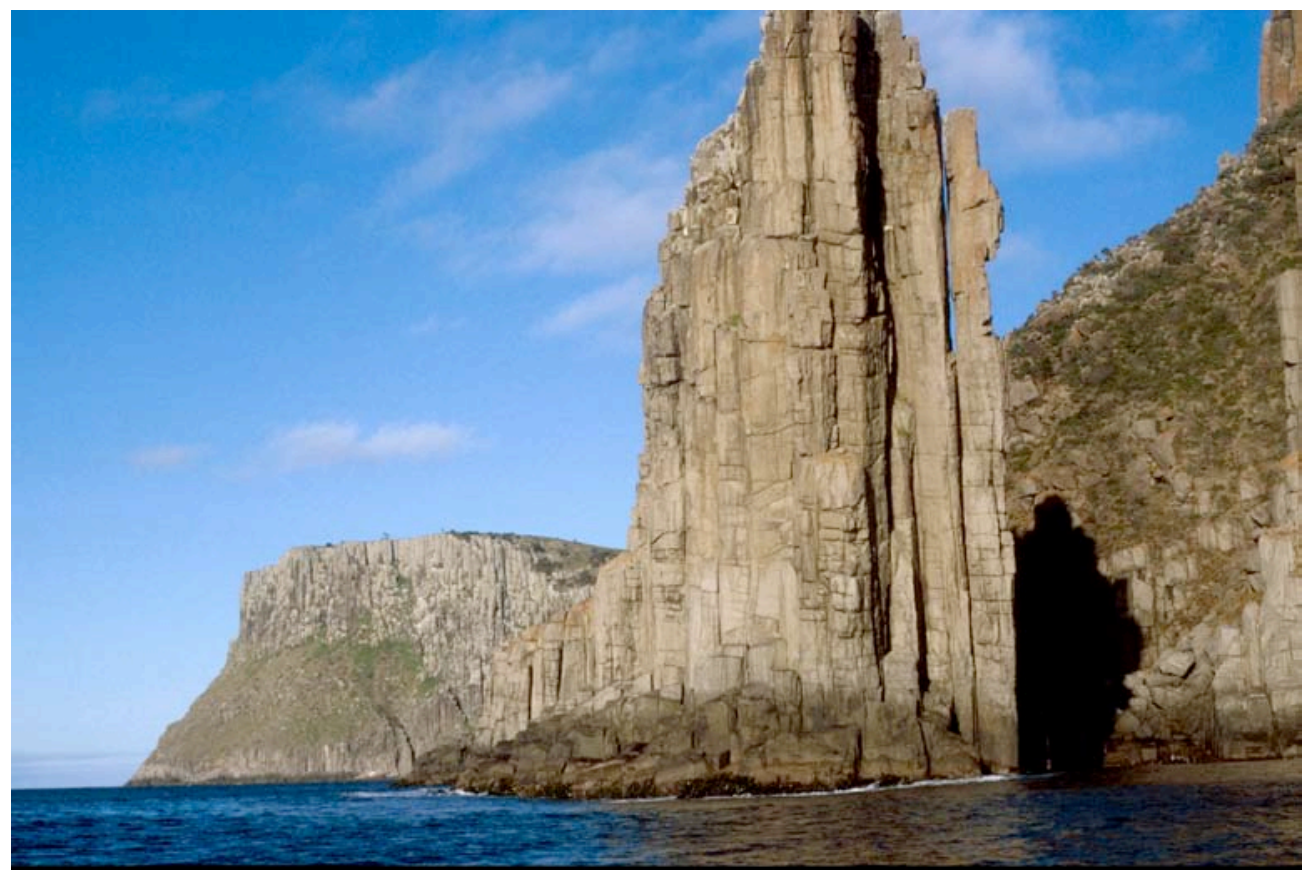

Figure 10. Dolerite columns forming cliffs at Cape Pillar on the southeastern coast of Tasmania. Péron described these rocks as prisms and needles of basaltic appearance. Photo by courtesy of the Department of Mineral Resources, Hobart, Tasmania.

Some of the characteristics used at that time in the identification of volcanic rocks included the presence of pores, vesicles, a scoria-like appearance and a glassy texture (Carozzi 2000, p. 9). Bailly believed that he had detected such diagnostic features in a number of the Tasmanian specimens, now known to be dolerite, and even claimed to have recognised lava flows. This 'evidence', together with the similar appearance of dolerite and basalt in both outcrop and in hand specimen, persuaded him to identify these Tasmanian rocks as basalt. He even referred to higher ground on the island's southwestern coast as a volcanic plateau.

Bailly conceded that even with the aid of a hand lens he had difficulty in identifying individual minerals in the fine grained rocks he believed to be basalt. As Carozzi (2000, pp. 353-354) has pointed out, the diagnostic properties of many minerals were then still poorly defined. This was particularly so in the case of doubly-terminated minerals, at that time often referred to as 'schorl' $\longrightarrow$ a term that could include tourmaline, augite, hornblende, olivine and even feldspar crystals. It is perhaps not surprising therefore that Bailly 
misidentified pyroxene as amphibole in some of his Tasmanian 'basalt' samples. Some ten years later, by which time the science of mineralogy had made considerable progress, he confidently described the presence of pyroxene in basalt he had collected at the Ile de France (Mauritius) in 1801 (Bailly 1812, 1825). The mineralogist may however have been correct in his surmise that "some crystals of shiny and greasy appearance seemed to have the characteristics of quartz", as this mineral occurs in some Tasmanian dolerites. In several 'lava' pebbles, collected from a riverbed, he identified 'chrysolite' and described it as "sometimes occurring in pyramidal form, sometimes flaky and often formless or decomposed", and of "several shades of yellow, greenish, shiny white and pink". The mineral was most likely fayalite olivine, which is present in granophyres, into which some of the Tasmanian dolerites grade (Farmer 1985, p. 67). In pores, cavities and fissures he noted "infiltrated material", including chalcedony, calcite and zeolite. ${ }^{18}$

Some of the outcrops of Tasmanian dolerite that Bailly examined gave him the impression that these rocks might belong to the trap formation, particularly as they seemed to form "beds" and appeared in terrace-like outcrops. ${ }^{19}$ The term 'trap', a Swedish word for stair or step, did not then have a precise meaning for naturalists. It had been applied to superposed dolerite sills and later to sequences of basaltic lava flows with a step-like appearance in outcrop, as well as to dolerites with a columnar structure and to various other rocks of igneous origin. Werner, who described such rocks as fine-grained, dark-green to black, composed largely of hornblende and feldspar and occurring in parallel beds, believed trap to be of aqueous origin and to belong to the category of the Primitive (Wagenbreth 1967, p. 109). As both Dolomieu and Depuch seemed to agree with Werner's theory on the origin of trap, it is likely that Bailly held similar views. ${ }^{20}$ Later in the voyage, Depuch identified specimens of a Jurassic dolerite from Prospect Hill in the Sydney Basin (Branagan and Packham 2000, p. 115) as "trapp" and "consequently primitive". ${ }^{21}$ When the German writer, Karsten $(1808$, p. 83) commented on the presence of trap rock at Botany Bay he may have been referring to Depuch's discovery.

The news that 'volcanic' rocks had been found in Australia aroused considerable interest in Europe and attracted comments in the literature. Zimmerman (1810), writing in German, seemed sceptical about such a discovery when he stated that "as currently only some, in part still doubtful facts are available to us, the question of if and to what extent volcanoes have contributed to the formation of New Holland, its islands and its mountains, is uncertain". He went on to mention the sighting, by the then lieutenant James Cook in 1770, of volcano-like hills on Australia's east coast (the Glass House Mountains, volcanic plugs of Tertiary age), and the finding of pumice by Matthew Flinders on the same coast (probably derived from volcanoes in New Zealand), and referred to these phenomena as "traces of volcanoes, which are less subject to doubt than the basalts [of Depuch Island], with respect to their volcanic nature" (Zimmermann 1810, p. 848). He concluded, rather confusingly that "at least some parts of both New South Wales and the west coast [of Australia] appear without doubt to be volcanic" (Zimmermann 1810, p. 865).

Vallance (1975, p. 24) has suggested that Pallas' idea (1782, pp. 81-83) of enormous subterranean fires, possibly below the Indian Ocean, leading to volcanic eruptions that gave birth to the islands of the Moluccas, and of part of the Philippines and Australia, would have been known to German writers. It is possible, therefore, that Zimmermann expected that volcanic rocks would be found on the southern continent, and accepted the less than

\footnotetext{
18 Bailly, Catalogue, 25-26. (See note 3.)

Bailly, Catalogue, 42. (See note 3.)

Cordier, Extrait des leçons, 13-15. (See note 2.)

Depuch, L. 1802. Monsieur Depuch's opinion of the items lately sent from the mountains by M. Barralier, Nov. $13^{\text {th }}[1802]$. Mitchell Library Sydney, King Papers, v. 8, p. 71, CY 906, A1980-2.
} 
conclusive evidence of their presence. It was, in fact, not until 1836 that the first volcanic rocks were discovered in Australia (Mitchell 1838).

\section{MOUNTAINS, SEA-LEVEL CHANGES AND LIVING FOSSILS}

\subsection{The evidence for mountains in Australia}

When the French expedition reached Australia in 1801, little was known of the country's interior and its topographical expression. The work of Baudin and that of the English navigator Matthew Flinders (1774-1814) (Flinders 1814), who complemented each other in charting the then still unknown parts of Australia's southern coast, succeeded in laying to rest speculation that a sea, running from north to south, divided the large landmass into two separate and roughly equal parts. However, their exploratory work on land was largely confined to the continent's margins. The short inland excursions of Baudin's naturalists yielded only glimpses of the continent's physical features. Depuch's impression, when first sighting the western Australian coast, of a "low-lying or, at least, not very high" land, bordered by extensive sandy terrain, seemed to be confirmed by many of the naturalists' subsequent observations as the voyage progressed (Péron and Freycinet 2006, p. 60).

Depuch and Bailly alone among the expedition's naturalists, and perhaps Baudin himself, had the opportunity to journey short distances inland and to report on the topography of the terrain they encountered. Both of the mineralogists thought it likely that, despite the mostly low relief at the continent's margins, mountains existed in its interior. Depuch, following his ship-board observations of the hilly ground to the south of Geographe Bay, now known as the Leeuwin-Naturaliste Ridge, assumed that this elevated terrain also extended inland (Bonnemains et al. 2001, pp. 247-249). It was Bailly who, on his inland excursion along the Swan River in Western Australia, first observed "high mountains which appear to form a chain", and which we now recognize as the Darling Ranges. Misled by an error in taking his bearings, he believed that these ranges extended in an east-west direction and that they were connected to the coastal hills earlier described by Depuch. He went on to state that: "This chain which runs towards the centre of New Holland appears to me to be one of those that constitute the backbone of the country". ${ }^{22}$ Both of these uplands extend, in fact, along a parallel north-south trend.

In New South Wales, the two mineralogists referred to the uniform elevation of the Blue Mountains as "a vast curtain bordering the north-west horizon . . . not marked by a single indentation or a single peak" (Péron and Freycinet 2006, p. 308). Baudin himself claimed to have penetrated further than the English into the interior, to the west of Sydney. There is, however, no independent evidence to support this assertion. As the then unconquered barrier of the Blue Mountains begins its rise some sixty kilometres from the coast, the distance of seventy-five to eighty milles (about $150 \mathrm{~km}$ ), over which Baudin believed he had travelled inland, was clearly excessive. However, his observations of the topography along part of Australia's eastern seaboard led him to predict the existence of a lengthy mountain range that extended in a north-south direction from Port Stephen (some 200 kilometres north of Sydney) to Wilson's Promontory on the continent's southern coast (see Figure 2). ${ }^{23}$ When sailing off the coast of New South Wales, the sighting of "a chain of extremely high mountains" (Baudin 2004, p. 427), most likely parts of the Snowy Mountains, seems to have confirmed him in his view that a major chain of mountains, today known as part of the Great Dividing Range, was aligned more or less parallel to the eastern

22 Bailly, Observations minéralogiques, 3. (See note 10.)

23 Baudin, letter to Jussieu. Published in La gazette nationale ou le moniteur universel, 9 September 1803, pp. $1551-1552$. 
margin of Australia. Péron also recognized that the Blue Mountains made up only a small section of a much more extensive chain. He went further than his captain and, probably relying partly on the reported sightings of higher ground by earlier navigators, confidently asserted that a range of mountains extended along the east coast from the northern tip of New Holland as far south as Tasmania. His assumed continuity of Australia's eastern highlands led him to suggest that "these mountains of New Holland are remarkably similar to the Andes of South America in situation", except that here they are located on the eastern side of the continent (Péron and Freycinet 2006, pp. 307-308). The naturalist expressed some contrary opinions about the height and attractiveness of Australian topography. On the one hand he likened the more elevated ground of some parts of the continent to "wretched mole-hills in comparison to our great European mountains" (Péron and Freycinet 2003, p. 110), while, on the other hand, he was able to "admire the lofty mountains" and "the broad plateaux" of Tasmania's interior (Péron and Freycinet 2006, p. 175).

Péron's geological investigations in Tasmania, where the land has some appreciable relief, seems to have inspired him to write down his thoughts on the genesis of Primitive mountains and on the deposition of the Secondary rocks (Plomley et al. 1990). His views, which were shared by Depuch, confirmed his belief in an aqueous origin of the first-formed rocks and also suggest the existence of sub-marine valleys. The extracts below, written in the evocative language often used by Péron when proclaiming his ideas, present some of the major points of his thesis:

In an undoubtedly very far-off era, lost in the mists of time, all the highest peaks of this island were still hidden away at the bottom of the ocean. Everything was covered by the waves. Over the centuries the mass of water diminished and (this diminution being too gradual for us to perceive, but not passing unnoticed by Nature) the ground must have risen imperceptibly towards the surface of the sea.

By and by, the peaks appeared. Coming forth from Nature's flank in the earliest days of the world, they were necessarily formed of primitive rock; and indeed all of them are a very beautiful granite....

Our peaks, scarce and solitary at first, multiply imperceptibly. They grow bigger at their base and join together. The chains of reefs begin; they stretch out at the water's surface, they grow longer still, they curve and break off and the first elements of valleys start to be definable above the sea.

Some of these developing valleys, almost completely concealed beneath the water by the very disposition of rocks and reefs surrounding them, can and actually do find themselves protected more effectively from the action of the waves. Calmer below the surface, these gradually deposit there all the accumulated debris from the nearby rocks which they have destroyed or eaten away. It is then that the first deposits begin; it is then that the formation takes place of those masses of secondary rock which I have mentioned as occurring at several point along the coast and as always lying on top of the primitive rock. ...

Indeed, the profound calm of these first underwater valleys, the quality of the softer soil- everything was favourable to Nature's plans. She developed there the potent germ of life and multiplication. From that moment on, the uniformity of the deposits disappeared with their homogeneity. Mixed with the remains of shellfish, the debris of the primary rocks was thereby successively modified in twenty different ways. According to whether the calcareous particles were more plentiful or more rare, the sediment acquired a particular character; and since, in the same period, it became further degraded by fucus [bull kelp] and other marine plants, a notable change in its essential composition was bound to follow (Plomley et al. 1990, pp. 19-20).

Péron seems to have been the first to comment on the separation of Tasmania from the Australian mainland. However his speculations were not based on geological grounds. Before his departure from France, the then newly-formed Société des observateurs de l'homme had entrusted him with the tasks of collecting information on the Australian 


\section{WOLF MAYER}

Aborigines and, in a note by George Cuvier, had provided him with some written instructions (Cuvier 1978, pp. 173-176). The naturalist noted some physical differences between the inhabitants of Van Diemen's Land (Tasmania) and those living on the continent, particularly with respect to the nature of their hair: short, woolly and fuzzy, in the case of the former; long, straight and smooth, in the case of the latter. He concluded from this that the two groups of Aborigines represented different races and argued that the occupation of these lands occurred after the separation of Tasmania from the mainland, as otherwise they would be inhabited by a common race (Péron 2007, pp. 33-34). Péron, in his pioneering studies of Australian anthropology, could not have envisaged that about 12,000 years ago rising sea levels cut off Tasmania from the continent, leading to the complete isolation of its population for some 500 generations and probably resulting in some degree of genetic drift (Mulvaney and Kamminga 1999, pp. 339-340).

\subsection{Sea level changes and their causes}

Péron took a particularly interest in geological topics with were linked to his interests in the field of zoology. Soon after his return to Paris, he published an article in which he announced the discovery of the fossilized remains of corals in Australian rocks now occupying a position well above present day sea level. He stated that the southern continent was "the only landmass from which this phenomenon had not previously been recorded", and regarded the find as the final piece of evidence which proved that an ancient ocean had once dominated the entire Earth (Péron 1804, p. 467). He then pondered the question of whether part of the sea floor had been elevated to form dry land or whether the sea level had fallen. The only force he could envisage that was powerful enough to raise the land was volcanism. However such activity caused "disorder and turmoil" for which he had found no evidence at the localities he had examined. The only possible explanation was therefore that the sea had retreated from the land. His earlier conclusions with respect to the deposition of 'Alluvium' on the western Australian coast strengthened him in this view.

There remained, however, the tantalising question of "what became of the sea's waters as they abandoned the summits of the mountains formed at their depths"? "Here", he went on misleadingly, "the voices of observation and experience have fallen silent" and, further, that the search for an answer to this question offered "great possibilities for imagination, enthusiasm and hypotheses" (Péron 2007, pp. 44-46). Péron's somewhat evasive and unsatisfactory answer to explain the withdrawal of the sea from the land attracted the criticism of Jean-Baptiste Lamarck (1744-1829). The latter pointed out that marine shells and corals had been found in the high Pyrenees, some 3,000 metres above the present level of the sea, and that it would have required a doubling of the ocean volume for it to have occupied this elevated position. He chided Péron for his simplicity of thought and remarked: "Here we cannot prevent ourselves from noting that the author does not seem to have envisaged the whole extent of the problem he has undertaken to resolve" (Lamarck 1805 , p. 33). Lamarck $(1802,1964)$ had published his own theory to explain changes in sea level, which he attributed to the slow migration of the Earth's equatorial bulge resulting in a steady displacement of ocean basins and the progressive emergence of land that was formerly covered by the sea. Péron knew of Lamarck's hypothesis but seems to have chosen to ignore it.

While Péron generally appears to have envisaged earth processes, such as the emergence of mountains and the withdrawal of the sea from the land, as having operated in a slow, seemingly uniform and orderly fashion, he occasionally invoked catastrophic events to explain geological situations. When finding marine shells more than 200 metres above sea level in Tasmania in terrain he believed to consist mostly of 'Primitive' rocks, he concluded that "the Earth, at this extreme point of the eastern world, experienced its 
upheavals and catastrophes; it was, as everywhere else, ravaged by volcanic fire and submerged beneath the ocean" (Péron and Freycinet 2006, p. 196). His practice of calling on both gradual and chaotic processes to resolve questions about Australian geology introduces a measure of inconsistency into his ideas.

\subsection{Living fossils}

Of particular interest to European naturalists were reports of some types of mollusks found living on Australia's beaches, which were only known as fossils in Europe (Bonnemains et al. 2001, p. 267). Lamarck, when describing a specimen of Trigonia, which Péron had found on beaches of the continent's southern coast, saw in its living presence confirmation of his theory that animals did not become extinct but merely underwent small changes over time:

I believe that if any species in the animal kingdom have been lost, this was only the case among terrestrial animals of a certain size. ... As for small species, and especially those that live in the sea, they have the means to escape [hunting by humans] and among them are truly none that have really been lost. They have only undergone mutations ... which have changed them in such a way that the remains we find of those animals that have lived in the past show some differences from those of the same species which are alive today (Lamarck 1804, pp. $352-353)$.

When von Buch became aware of the survival of genera of mollusks in Australia, long since extinct in Europe ${ }^{24}$ his thoughts took a different turn. He was conscious of the fact that little was known of the geology of the southern lands and that it was important to assemble the isolated pieces of evidence from these parts of the world "so that we can at least make assumptions of the extent to which the geological laws of our hemisphere can be confirmed or may change" (von Buch 1814, p. 234). It seemed to him that the finding of socalled 'living fossils' in Australia might require a fresh look at the widely held view advocated by Werner, his former teacher, that sediment had been deposited uniformly in a universal ocean. The information brought back from Australia prompted von Buch to suggest the possibility that local sedimentation may have produced unique deposits there (von Buch 1814, p. 235).

\section{RECEPTION OF THE EXPEDITION'S GEOLOGICAL FINDINGS}

The number of natural objects collected in Australia by members of the Baudin expedition is simply staggering. Horner $(1989$, p. 357) noted that the two ships returned to France with a cargo of well over 200,000 items. Most of these specimens were of a zoological and botanical nature and included thousands of new species. The recorded number of 796 geological specimens taken back to France seems modest by comparison. It is most unfortunate that, while many of the plant and animal specimens from Australia still form part of collections held in French museums, particularly in the National Museum of Natural History in Paris, attempts by the author to locate the rock and mineral samples have not, so far, been successful.

While those with an interest in the natural sciences in France, including many among the general public, shared in the excitement of the arrival of the wondrous faunal and floral specimens from the southern continent, the rock and mineral samples and the significance of the geological discoveries, received less attention. The unfortunate death of Depuch on the homeward voyage, and the added misfortune of the loss of his journal, denied the scientific community the comprehensive account and interpretation of the continent's coastal geology,

$24 \quad$ Bailly, Catalogue, 6-7. (See note 3.) 


\section{WOLF MAYER}

which he had intended to write, and which could well have made an important contribution to contemporary thinking about the Earth. Péron himself made this point very tellingly:

Why was it necessary that my unfortunate friend M. Depuch-too early struck down by a mortal illness - should not be able to observe what arose from the great phenomena that thronged (as it were) about us? A sound education, rare wisdom and strict judgement, were combined in this skilful geographer [sic] with the most intrepid dedication and unflagging activity. He had already prepared important material for the geological account of New Holland and he alone was capable of giving it all the weight of which it is susceptible.

In a footnote he added:

Upon leaving us at Port Jackson to return to Europe, M. Depuch took all his manuscripts with him. It is painful to have to say that the family friend, in whose house in the Ile de France he ended his days, allowed all our honourable colleague's work to go astray - an irreparable loss to Science and, above all, to our expedition (Péron 2007, pp. 32-33).

A manuscript note held in the National Archives in Paris, dated 27 June 1804, states that "Bailly, mineralogist, requested all the papers relating to his voyage, and the catalogue of Depuch, which he received". A government regulation required that the returning naturalists and ships' officers surrender their journals and catalogues at the end of the voyage. The fact that Bailly was able to reclaim both his own manuscripts and the catalogue of Depuch, suggests that the latter had prepared a duplicate copy and entrusted it to his colleague before starting on his homeward voyage. Von Buch, the first geologist to examine and assess the geological collection brought back to France, at the time housed in the rooms of the Council of Mines in Paris, referred to the catalogues of both Bailly and Depuch (von Buch 1814). But while Bailly's catalogue has survived that of his senior colleague seems to have been lost.

As Bailly was not given the opportunity to write about the expedition's geological findings in Australia or to work on its collections, the presentation of its geological achievements lacked a dedicated and knowledgeable spokesman. In the absence of such expert advice, Antoine Laurent de Jussieu (1748-1836), then professor of botany at the Jardin des Plantes and director of the Museum of Natural History, made a somewhat negative assessment of the work of the mineralogists:

One will not be surprised that by carrying out research confined to the coasts, most of them deserts or covered in trees, with neither high mountains nor ravines in which to observe the various layers of the land, nor with any mine workings, the mineralogists Depuch and Bailly, have not been able to collect more than a small number of minerals, insufficient to give an exact idea of the geology of this country. That which they have brought back serves at most to give a general understanding of the surface of the land they have visited, and to indicate the distinction between the epochs in which the mineral substances of this land have been produced (Jussieu 1804, p. 7).

The geological results of the expedition published in the official history of the voyage by Péron (1807), and later augmented by Freycinet (Péron and Freycinet 1816, 1824), while of considerable interest, were presented in a disjointed fashion within the context of the voyage's history and progression and did not provide the reader with a cohesive and comprehensive account of the expedition's achievements in this field. The accounts nevertheless provided a useful introduction to Australian geology for naturalists of future voyages of discovery to the southern continent, particularly to those participating in the expeditions led by Freycinet himself in 1817-1820 (Freycinet 1827), Phillip Parker King in 1818-1822 (King 1826), Duperrey in 1822-1825 (Duperrey 1826) and Dumont d'Urville 
in 1826-1829 (Dumont d'Urville 1832-1833). Apart from Lamarck, the Baudin expedition's geological work attracted the interest of a number of other scientists, including Lacépède (1804), Fitton (1826) (see also Branagan and Moore 2008), Cuvier (1825), and Darwin (1842).

The first Australian to comment in some detail on the geological work of the Baudin expedition was Ralph Tate (1840-1901), Professor of Natural History at the University of Adelaide. While recognising the published contributions of Depuch and Bailly, he heaped particular praise on the work of Péron. "Few geologists" [sic], he wrote, "have been more in advance of their age in which they lived, or have suffered so long an undeserved oblivion, as Péron" (Tate 1893, pp. 6-7). In more recent years the Baudin expedition's geological work has received more detailed attention in the writings of Vallance (1975, 1981-1982), Branagan 2002, and Mayer (2003, 2005, 2007, 2008 and 2009, in press).

\section{CONCLUSION}

The investigations carried out by members of the Baudin expedition in Australia provided European scientific observers, as well as the general public, with the first detailed information about the geological constitution of the southern land. The methods the naturalists employed in their studies and the theories and ideas that directed the analyses and evaluations of their findings provide us with an awareness of advances in the study of the Earth at a time when geology began to emerge as a science in its own right. While the expedition's geological findings did not then receive the full credit they deserved, they did provide a range of material for debate among European naturalists and became more widely known by their inclusion in a number of popular books on foreign travel and discoveries.

\section{APPENDIX: QUESTIONS ON NATURAL HISTORY ${ }^{25}$}

\section{Mineralogy}

Are the coastlines vertical or sloping? Are they broken or continuous?

Are they composed of rocks or dunes?

If they are of dunes, what is the composition of the sand that forms them? Does the sand contain metallic minerals? Does it contain petrifactions and of what kind are they? If the coastline is formed of rocks, are they granite and, if so, of what type? Of what different stone is this granite composed? ${ }^{26}$

If it is not granite, is the rock foliated, hard or not? Mixed with other stones or not? Is it basalt or hornstone? ${ }^{27}$ Is it just slate, hard or soft? Is it steatite?

Finally, of what colour are all the different types of stone?

If it is not one of the above rocks, is it marble, of one colour or multi-coloured? Does this marble occur in horizontal beds or in vertical sections? Are petrifactions present, and of what kind are they?

If it is not marble, is it sandstone, pure or mixed?

\footnotetext{
25 Archives nationales, Paris, 5JJ35; National Library of Australia, Canberra, Baudin Papers, G 2165 (Reel 11), pages not numbered. The unsigned document may have been written by Charles Pierre Claret Fleurieu (1738-1810), who prepared the instructions for Baudin's voyage, or by Pierre-Alexandre Forfait (1752-1807), the then Minister for the Navy.

26 The compiler of this questionnaire acknowledges here that the term granite was at that time applied to a variety of different rock types.

27 There was much confusion at the time about the properties and the identification of hornstone (roche de corne). The term was often applied to describe both amphibolite and hornfels. Dolomieu considered it to be a rock rich in hornblende (Cordier 1796, p. 14). Confusingly, in Sweden the term 'hornstone' seems to have been equated with trap (see Carozzi 2000, p. 576).
} 
If the stone is calcareous, is it pure; that is to say, is it homogeneous, fine or coarse? Are petrifactions present, and of what kind are they?

If mountains exist, in what direction are the most elevated ridges aligned?

Are the summits snow-covered or not? What is the height of the mountains above sea level? If the summits are snow-covered, what is the elevation of the parts permanently covered in snow? Or else, does the snow only cover the summit? Is the snow-cover of great thickness or not? Are streams issuing from the snow?

If some of the mountains can be visited, are there any indications of mineral deposits, and of what kind? Are precious stones found there, such as rock crystal, agate, jade, jasper, hyacinth or garnet?

What type of stones, coarse or fine, are found in the beds of streams, and what metallic minerals occur there? Are they abundant?

If the terrain is volcanic, do lavas occur in flows or as prisms, vertical or inclined, of a single stream or branched? Do these lavas contain nests of precious stones? Does one find among these lavas glass that is compact or hair-like, ${ }^{28}$ pumice stone, zeolites, etc.?

As the productions of marine insects cover the rocks, the sand banks and other coral deposits, with madrepores and other productions of polyparies, when coasts covered with these productions are encountered, one asks what is the thickness of these deposits, do they descend so deeply into the sea that one can presume that a small island or projection or some other kind of reef can be formed merely by the deposit produced by the work of polyps? ${ }^{29}$

\section{ACKNOWLEDGEMENTS}

I would like to thank Gabrielle Baglione of the Muséum d'histoire naturelle at Le Havre, Marie-Noëlle Maisonneuve of the École des mines and Claudine Biloux of the École polytechnique in Paris for allowing me access to the manuscript collections housed in their respective archives. I am grateful to Professor Philippe Taquet of the Muséum national d'histoire naturelle in Paris for his comments on the manuscript and for providing information and contacts in France, and to Professor Margaret Sankey of the Department of French Studies at Sydney University for her helpful remarks and for providing a translation from the French of the confusingly written last paragraph in the Appendix. Many thanks go to Richard Barwick, of the Research School of Earth Sciences at the Australian National University, for his generous help in preparing the map and enhancing the quality of some of the photos. I also thank John Everard of the Department of Mineral Resources in Hobart, Tasmania, for supplying a number of the photographs used in this article.

\section{ARCHIVES}

Archives de l'Académie des sciences, Paris.

Archives nationales de France, Paris.

École des mines, Paris.

École polytechnique, Paris.

La Collection Lesueur du Muséum d'histoire naturelle du Havre.

Mitchell Library, Sydney.

Muséum national d'histoire naturelle, Paris.

National Library of Australia, Canberra.

28 This term may refer to ropy lava of the pahoehoe type.

29 The document appears to have been written in haste and is not always easy to follow. The last paragraph in particular is badly and confusingly worded. Essentially, the questioner seems to ask if corals and their debris can result in the formation of islands or reefs, and at what depth such features start to form. 


\section{REFERENCES}

Bailly, J. C. 1812. Détails géologiques. From : Milbert, J. G. Voyage pittoresque à l'Ile de France, au Cap de Bonne Espérance, et à l'Ile Ténériffe, pp. 92-105. Paris: A. Nepveu.

Bailly, J. C. 1825. Geognostische Bemerkungen über Ile de France. Zeitschrift für Mineralogie 19: $136-146$.

Baudin, N. 1974, 2004. The Journal of Post-captain Nicolas Baudin, Commander-in-chief of the Corvettes Géographe and Naturaliste. Assigned by Order of the Government to a voyage of Discovery. Translated from the French with a preface by Christine Cornell. Adelaide: The Friends of the State Library of South Australia.

Bonnemains, J., Argentin, J. M. and Marin, M. 2001. Mon voyage aux Terres Australes. Journal personnel du commandant Baudin. Ville du Havre: Imprimerie Nationale Éditions.

Branagan, D. 2002. Australian stratigraphy and palaeontology: the nineteenth century French contribution. Comptes rendus palevol 1: 657-662.

Branagan, D. and Packham, G. H. 2000. Field Geology of New South Wales. Sydney: New South Wales Department of Mineral Resources.

Branagan, D. and Moore, D. T. 2008. W. H. Fitton's Geology of Australian Coasts. Historical Records of Australian Science 19: 1-51.

Buch, L. von. 1814. Einige Bemerkungen über die geognostische Constitution von Van Diemens Land. Magazin für die Neu Entdeckungen in der Gesammten Naturkunde 6: 234-240.

Carne, J. E. 1903. The Kerosene Shale deposits. Memoirs of the Geological Survey of New South Wales, Geology No. 3. Sydney: William Applegate Gullick, Government Printer.

Carozzi, A. 2000. Manuscripts and Publications of Horace Bénédict De Saussure. On the Origin of Basalt (1772-1797). Carouge-Genève: Edition Zoe.

Cuvier, G. 1825. Recherches sur les ossemens fossiles. Paris: Dufour \& d'Ocagne.

Cuvier, G. 1978. Note instructive sur les recherches à faire relativement aux différences anatomiques des diverses races d'homme. In: Aux origines de l'anthropologie française: les mémoires de la Société des Observateurs de l'Homme en l'an VIII, edited by J. Copans and J. Jamin, 173-176. Paris: Le Sycomore.

Darwin, C. 1842. The Structure and Distribution of Coral Reefs. London: Smith, Elder.

Dolomieu, D. 1794a. Distribution méthodique de toutes les matières dont l'accumulation forme les montagnes volcaniques, ou tableau systématique dans lequel peuvent se placer toutes les substances qui ont des relations avec les feux souterrains. Journal de physique, chimie et histoire naturelle 1: 102-125.

Dolomieu, D. 1794b. Mémoire sur les roches composées en général, et particulièrement sur les pétrosilex, les trapps et les roche de corne, .. . Journal de physique, chimie et histoire naturelle 1: 175-200, 241-263, 406-428; 2: 82-105.

Drexel, J. F. and Preiss, W. V. 1995. The geology of South Australia, Vol. 1, The Precambrian. South Australia, Geological Survey, Bulletin, 54.

Dumont d'Urville, J. S. C. 1832-1833. Voyage de découvertes autour du monde et à la recherche de La Pérouse par M. J. Dumont d'Urville, capitaine de vaisseau, exécuté sous son commandement et par ordre du gouvernement, sur la corvette l'Astrolabe, pendant les années 1826, 1827, 1828 et 1829. Paris: Roret.

Duperrey, L. I. 1826. Voyage autour du monde. Exécuté par ordre du Roi sur la corvette de Sa Majesté la Coquille pendant les années 1822, 1823, 1824 et 1825. Paris: Arthus Bertrand.

Duyker, E. 2006. François Péron: An Impetuous Life-Naturalist and Voyager. Melbourne: Miegunyah Press.

Farmer, N. 1985. Kingsborough, Explanatory Report Geological Atlas 1:50 000 Series, Sheet 88 (8311N) Hobart: Tasmania Department of Mines.

Fitton, W. H. 1826. An Account of some Geological Specimens from the Coasts of Australia. London: W. Clowes.

Flinders, M. 1814. A Voyage to Terra Australis. London: G. and W. Nicols.

Freycinet, L. 1811. Voyage de découvertes aux Terres Australes, exécuté par ordre de Sa Majesté l'Empereur et Roi, sur les corvettes le Géographe, le Naturaliste, et la goëlette le Casuarina, pendant les années 1800, 1801, 1802, 1803 et 1804. Atlas (Historique) Paris: Imprimerie Impériale. 


\section{WOLF MAYER}

Freycinet, L. 1827. Voyage autour du monde, entrepris par ordre du Roi, exécuté sur les corvettes de S. M. l'Uranie et la Physicienne pendant les années 1817, 1818, 1819 et 1820. Paris: Pillet Ainé.

Hickman, A. H. and Smithies, R. H. 2001. Roeburne, Western Australia. Geological Survey of Western Australia 1:250 000 Geological Map and Explanatory Notes. Sheet SF 50-53.

Horner, F. 1987. The French Reconnaissance: Baudin in Australia 1801-1803. Melbourne: Melbourne University Press.

Hutton, J. 1795. Theory of the Earth with Proofs and Illustrations, 2 vols. Edinburgh: William Creech.

Jussieu, A. L. 1804. Notice sur l'expédition à la Nouvelle-Hollande, entreprise pour des recherches de géographie et d'histoire naturelle. Annales du Muséum d'histoire naturelle 5: 1-11.

Karsten, D. L. G. 1808. Mineralogische Tabellen mit Rücksicht auf die neuesten Entdeckungen. Berlin: Heinrich August Rottmann.

Kendrick, W. G., Wyrwoll, K. H. and Szabo, B. J. 1991. Pliocene-Pleistocene coastal events and history along the western margin of Australia. Quaternary Science Review 10: 419-439.

King, P. P. 1826. Narrative of a Survey of the Intertropical and Western Coasts of Australia. London: John Murray.

Lacépède, E. 1804. Mémoire sur plusieurs animaux de la Nouvelle-Hollande dont la description n'a pas encore été publiée. Annales du Muséum d'histoire naturelle, 4: 184-211.

Lamarck, J.-B. 1802. Hydrogéologie ou recherches sur l'influence qu'ont les eaux sur la surface du globe terrestre... Paris: Agasse et Maillard.

Lamarck, J.-B. 1804. Sur une nouvelle espèce de Trigonie, et sur une nouvelle espèce d'Huitre, découvertes dans le voyage du capitaine Baudin. Annales du Muséum d'histoire naturelle 4: $351-359$.

Lamarck, J.-B. 1805. Considérations sur quelques faits applicables à la théorie du globe, observé par M. Péron dans son voyage aux terres australes, et sur quelques questions géologiques qui naissent de la connaissance de ces faits. Annales du Muséum d'histoire naturelle 6: 26-52.

Laumet, J.-C. 2006. Une île 'girondine' en Terres Australes: l'île Depuch. Le mois scientifique d'Aquitaine 268/269: 11-14.

Lowry, D. C. 1967. Busselton and Augusta, Western Australia. Geological Survey of Western Australia 1:250,000 Geological Map and Explanatory Notes. Sheets S1/50-55 and S1/ 50-59.

Mayer, W. 2003. A first geological assessment of the Sydney-Blue Mountains region by the visiting French mineralogists Joseph Charles Bailly and Louis Depuch, in 1802. Abstract $17^{\text {th }}$ Australian Geological Convention, Hobart, 31.

Mayer, W. 2005. Deux géologues français en Nouvelle-Hollande (Australie): Louis Depuch et Charles Bailly, membres de l'expédition Baudin (1801-1803). Travaux du Comité français d'histoire de la géologie, $3^{e}$ série, 19: 95-112.

Mayer, W. 2007. The quest for limestone in colonial New South Wales, 1788-1825. In: Four Centuries of Geological Travel: The Search for Knowledge on Foot, Bicycle, Sledge and Camel, edited by P. N. Wyse Jackson, 325-342. London: The Geological Society, Special Publications 287.

Mayer, W. 2008. Early geological investigations of the Pleistocene Tamala Limestone, Western Australia. In: History of Geomorphology and Quaternary Geology, edited by R. H. Grapes, D. Oldroyd and A. Grigelis, 279-293. London: Geological Society, Special Publications 301.

Mayer, W. 2009, in press. Les travaux géologiques de François Péron en Australie. A la conquête des Terres Australes (1800-1804): de la découverte à la collecte. Le Havre: Muséum d'histoire naturelle.

Mitchell, T. L. 1838. Three Expeditions into the Interior of Eastern Australia; With Descriptions of Recently Explored Regions of Australia Felix, and of the Present Colony of New South Wales. London: T. and W. Boone.

Mohs, F. 1822-1824. Grundriss der Mineralogie. Dresden: Arnoldsche Buchhandlung.

Mohs, F. 1825. Treatise on Mineralogy, translated from the German by W. Haidinger. Edinburgh: Constable; London: Hurst Robinson.

Muhling, P. C. and Brakel, A. T. 1985. Mount Barker-Albany, Western Australia. Geological Survey of Western Australia 1:250 000 Geological Map and Explanatory Notes. Sheets SI/50-11 and $50-15$.

Mulvaney, J. and Kamminga, J. 1999. Prehistory of Australia. Sydney: Allen and Unwin. 
Ospovat, A. M. 1971. Abraham Gottlob Werner: Short Classification and Description of the Various Rocks, translated with an introduction and notes. New York: Hafner.

Pallas, P. S. 1782. Observations sur la formation des montagnes, et les changemens arrivés à notre globe, pour servir à l'histoire naturelle de M. le Comte de Buffon. St Pétersbourg; et se trouve à Paris: Chez Méquignon l'aîné.

Péron, F. 1804. Sur quelques faits zoologiques applicables à la théorie du globe. Journal de la physique, chimie et d'histoire naturelle 59: 463-479.

Péron, F. 1807. Voyage de découvertes aux Terres Australes, exécuté par ordre de Sa Majesté l'Empereur et Roi, sur les corvettes le Géographe, le Naturaliste, et la goëlette le Casuarina, pendant les années 1800, 1801, 1802, 1803 et 1804. Paris: Imprimerie Impériale.

Péron, F. and Freycinet, L. 1816. Voyage de découvertes aux Terres Australes, exécuté par ordre de Sa Majesté l'Empereur et Roi, sur les corvettes le Géographe, le Naturaliste, et la goëlette le Casuarina, pendant les années 1800, 1801, 1802, 1803 et 1804, Historique. Tome II. Paris: Imprimerie Royale.

Péron, F. and Freycinet, L. 1824. Voyage de découverte aux Terres Australes, executé par ordre de Sa Majesté l'Empereur et Roi, sur les corvettes le Géographe, le Naturaliste, et la goëlette le Casuarina, pendant les années 1800, 1801, 1802, 1803 et 1804 (deuxième édition). Paris: Arthus Bertrand.

Péron, F. and Freycinet, L. 2003. Voyage of Discovery to the Southern Lands, 2nd edn, 1824, Book IV. Translated from the French by Christine Cornell. Adelaide: The Friends of the State Library of South Australia.

Péron, F. and Freycinet, L. 2006. Voyage of Discovery to the Southern Lands, 2nd edn, 1824, Books I to III. Translated from the French by Christine Cornell. Adelaide: The Friends of the State Library of South Australia.

Péron, F. 2007. Voyage of Discovery to the Southern Lands: Dissertations on Various Subjects, 2nd edn, 1824, Book V. Translated from the French by Christine Cornell. Adelaide: The Friends of the State Library of South Australia.

Playford, P. E. 1988. Guidebook to the Geology of Rottnest Island. Excursion Guidebook No. 2. Perth: Western Australian Division of the Geological Society of Australia and the Geological Survey of Western Australia.

Playford, P. E., Cockbain, A. E. and Low, G. H. 1976. Geology of the Perth Basin, Western Australia. Western Australian Geological Survey Bulletin 124.

Plomley, B., Cornell, C. and Banks, M. 1990. François Péron's natural history of Maria Island, Tasmania. Records of the Queen Victoria Museum 99: 1-50.

Prevost, M. and d'Amat, R. (eds). 1948. Dictionnaire de biographie française, Vol. 4. Paris: Librarie Letouzey et Ainé.

Rankin, L. R. and Flint, R. B. 1991. Streaky Bay, South Australia. South Australia Department of Mines and Energy 1:250 000 Geological Series and Explanatory Notes. Sheet S1/53-2.

Saussure, H.-B. de 1779. Voyage dans les Alpes précédés d'un essai sur l'histoire naturelle des environs de Genève. Neuchatel: Samuel Fauche.

Seddon, G. 1973. Abraham Gottlob Werner: history and folk-history. Journal of the Geological Society of Australia, 20: 381-395.

Tate, R. 1893. Century of geological progress. Australasian Association for the Advancement of Science 5: 1-69.

Touret, J. L. R. 2005. Le cours professé par Dolomieu en 1796 à la maison d'instruction de l'agence des mines. In: Dolomieu et la géologie de son temps, edited by J. Gaudant, 119-137. Paris: Mines Paris Les Presses.

Vallance, T. G. 1975. Origins of Australian geology. Presidential Address, Proceedings of the Linnean Society of New South Wales 100: 13-43.

Vallance, T. G. 1981-1982. Lamarck, Cuvier and Australian geology. Histoire et nature, 19-20: 133136.

Wagenbreth, O. 1967. Abraham Gottlob Werners System der Geologie, Petrographie und Lagerstättenlehre. Freiberger Forschungshefte, C 233: 83-156.

Werner, A. G. 1786. Kurze Klassifikation und Beschreibung der verschiedenen Gebirgsarten. Abhandlungen der Böhmischen Gesellschaft der Wissenschaften, auf das Jahr 1786. Prag und Dresden: In der Waltherischen Hofbuchhandlung. 


\section{WOLF MAYER}

Zimmermann, E. A. W. von 1810. Australien in Hinsicht der Erd-, Menschen- und Produktenkunde. Hamburg: Friedrich Perthes. 